\title{
Marine Mo biogeochemistry in the context of dynamically euxinic mid-depth waters: A case study of the lower Cambrian Niutitang shales, South China
}

\author{
Meng Cheng ${ }^{\text {a,b }}$, Chao Li ${ }^{a^{*}}$, Lian Zhou ${ }^{c}$, Thomas J. Algeo ${ }^{\text {acc,d }}$, Feifei Zhang ${ }^{\text {e }}$, Stephen \\ Romaniello ${ }^{\mathrm{e}}$, Cheng-Sheng Jin ${ }^{\mathrm{a}}$, Li-Dan Lei ${ }^{\mathrm{a}}$, Lian-Jun Feng ${ }^{\mathrm{f}}$, Shao-Yong Jiang ${ }^{\mathrm{c}, \mathrm{g}}$
}

${ }^{a}$ State Key Laboratory of Biogeology and Environmental Geology, China University of Geosciences, Wuhan 430074, China

${ }^{b}$ School of Earth Sciences, China University of Geosciences, Wuhan 430074, China

${ }^{c}$ State Key Laboratory of Geological Processes and Mineral Resources, China University of Geosciences, Wuhan 430074, China

${ }^{d}$ Department of Geology, University of Cincinnati, Cincinnati, OH 45221, U.S.A.

${ }^{e}$ School of Earth and Space Exploration, Arizona State University, Tempe 85287, U.S.A.

${ }^{f}$ Institute of Geology and Geophysics, Chinese Academy of Sciences, Beijing 100029, China

${ }^{g}$ State Key Laboratory for Mineral Deposits Research, Department of Earth Sciences, Nanjing University, Nanjing 210093, China

*Corresponding author. Tel: +86-27-67883606; Email address: chaoli@cug.edu.cn $1 / 30$ 


\section{Abstract}

Molybdenum (Mo) concentrations and Mo isotopes have been widely used as proxies for local and global redox conditions in early oceans ( $>520 \mathrm{Ma})$ that were stratified and characterized by dynamically euxinic mid-depth waters. However, the nature of the Mo cycle and accompanying isotopic fractionations in such oceans remain poorly known. To fill this gap, we conducted an integrated study of Mo isotopes and redox-sensitive trace element (RSTE) abundances in the Lower Cambrian Niutitang Formation at Yangjiaping, South China. This section accumulated on the northern shelf margin of the Nanhua Basin, a failed intracontinental rift basin with a good connection to the open ocean during the early Cambrian. The Niutitang Formation contains a 18-m-thick lower black shale member, and a $\sim 56$-m-thick upper gray silty shale member. The lower member (LM) is moderately to strongly enriched in Mo, $\mathrm{U}$ and $\mathrm{V}$, and heterogeneous in Mo isotopic composition $\left(\delta^{98} \mathrm{Mo}=-0.65 \%\right.$ to $+2.14 \%$ ), indicative of dominantly euxinic depositional conditions punctuated by ferruginous episodes (as shown by previously reported Fe speciation data). The upper member (UM) shows lesser enrichment of Mo, $U$ and V, higher Mo/U ratios, and intermediate and more uniform Mo-isotopic compositions $\left(\delta^{98} \mathrm{Mo}=+1.16 \%\right.$ o to $+1.71 \%$ ), indicative of weakly oxic to anoxic-euxinic depositional conditions. Geochemical profiles suggest that the LM-to-UM transition reflects a shift of the $\mathrm{O}_{2} / \mathrm{H}_{2} \mathrm{~S}$ chemocline from the water column to the sediment. Large $\delta^{98}$ Mo fluctuations in the LM may record variations of $\mathrm{H}_{2} \mathrm{~S}$ concentrations in the mid-depth euxinic waters. The intermediate and relatively uniform $\delta^{98}$ Mo values of the UM are attributed to the effects of a local Fe-Mn particulate shuttle.

In light of the observations at Yangjiaping and other contemporaneous sections in the Nanhua Basin, we propose a new marine Mo biogeochemical model for the early Cambrian ocean. In this model, an Fe-Mn reduction zone may have developed above mid-depth euxinic waters in nearshore areas of the Nanhua Basin due to relatively high availability of fluvial Fe-Mn oxides and their subsequent reduction below the chemocline. Within this redox framework, large sedimentary $\delta^{98}$ Mo variations observed for the Niutitang shales can be explained through the combined effects of Mo isotopic fractionation associated with adsorption onto Fe-Mn-oxides and spatially variable $\mathrm{H}_{2} \mathrm{~S}$ concentrations in the euxinic watermass. By compiling published data, we found that the large sedimentary $\delta^{98}$ Mo variations previously observed in the early Cambrian 
Nanhua Basin and in other Neoproterozoic-Cambrian marine basins can be similarly explained.

Our model provides a novel interpretation of the Mo biogeochemistry of early Earth oceans, within the framework of which Mo isotopes may serve to further our understanding of the oxygenation history of the Earth-surface system.

Keywords: Mo isotope; Nanhua Basin; Fe-Mn shuttle; Niutitang Formation; early Cambrian

\section{INTRODUCTION}

Recent studies of ancient seawater redox conditions have shown that anoxic, stratified oceans were dominant prior to and during the early Cambrian (hereafter termed "early oceans") (Li et al., 2010; Poulton et al., 2010; Planavsky et al., 2011; Feng et al., 2014). In these oceans, the surface and deep layers were characterized by oxic and ferruginous conditions, respectively, whereas a fluctuating, dynamically maintained "euxinic wedge" generally developed at mid-depths (Li et al., 2010; Li et al., 2015). The secular redox evolution of early oceans is reflected in variations between these three redox environments (Canfield et al., 2008; Poulton and Canfield, 2011; Guilbaud et al., 2015). Molybdenum (Mo) isotopes in organic-rich mudstones have been extensively utilized as a proxy to track the oxygenation state of ancient seawater at both a local and global scale (Arnold et al., 2004; Kendall et al., 2009; Dahl et al., 2010; Dahl et al., 2011; Kendall et al., 2011; Chen et al., 2015; Cheng et al., 2015). The interpretation of Mo isotopes as a global-scale redox proxy depends on the quantitative uptake of seawater Mo by the sediment under strongly euxinic conditions, thus reducing isotopic fractionation to near zero, versus large fractionations for Mo accumulating in oxic sediments. However, we still know relatively little about the Mo biogeochemical cycle of stratified early oceans.

The Nanhua Basin, a failed intracratonic rift basin in South China (Fig. 1A) that contains a continuous stratigraphic succession from the Cryogenian to the middle Cambrian, is an exceptional field area for the study of biological and geochemical processes in early oceans. The Cambrian strata in the Nanhua Basin record a rapid radiation of animals and the first appearance of many invertebrate phyla, i.e., the "Cambrian Explosion" (Knoll and Carroll, 1999; Erwin et al., 
2011). Studies have shown that the stratified structure characteristic of Neoproterozoic oceans extended into early Cambrian (Feng et al., 2014; Wen et al., 2014; Fu et al., 2016; Jin et al., 2016). To date, a number of Mo isotope studies have been undertaken on Cambrian strata of the Nanhua Basin (Lehmann et al., 2007; Wen et al., 2011; Xu et al., 2012; Chen et al., 2015; Wen et al., 2015), yielding results that seem contrary to observations from modern marine systems, for example, fluctuating isotopic compositions for euxinic sediments and relatively high $\delta^{98}$ Mo values for oxic sediments. These unusual features may have been due to the unique redox structure of the early Cambrian ocean, as discussed herein.

The earliest Cambrian Niutitang Formation at Yangjiaping, which was located at the shelf margin of the Nanhua Basin (Fig. 1B), records a distinctive stratigraphic succession (Fig. 1C) that reflects basinward movement of the euxinic wedge (Feng et al., 2014). Thus, this section provides an excellent opportunity to investigate changes in the Mo isotope composition of the sediment associated with the redox transition from euxinic to weakly oxic waters within a stratified ocean. In this study, we aim to explore the effect of the mid-depth euxinic wedge on the oceanic Mo biogeochemical cycle and to develop an integrated paleoceanic model for the early Cambrian Nanhua Basin. Furthermore, an improved understanding of Mo cycling within early oceans will help to better define the potential and limits of Mo isotopes as a proxy for reconstruction of paleocean redox conditions and the history of oceanic oxygenation.

\section{BACKGROUND: THE OCEANIC Mo CYCLE AND Fe-Mn SHUTTLES}

Mo is present in modern seawater mainly as the molybdate anion $\left(\mathrm{MoO}_{4}^{2-}\right)$, which is conservative and highly soluble, resulting in a relatively high concentration ( 104 nM) and a long residence time (0.44 Myr) in seawater (Miller et al., 2011). As the residence time of Mo is much longer than the ocean mixing time (1-2 ky) (Collier, 1985), seawater has a nearly uniform Mo isotopic composition $\left(\delta^{98} \mathrm{Mo}=+2.3 \%\right.$ ) (Siebert et al., 2003). Mo removal to the sediment varies as a function of watermass redox conditions. In oxic waters, Mo is removed slowly through adsorption to manganese oxides $\left(\mathrm{Mn}_{\mathrm{ox}}\right)$, yielding a light Mo isotopic composition $\left(\delta^{98} \mathrm{Mo}=-0.7 \%\right.$ ) in the adsorbed fraction (Barling and Anbar, 2004). Mo adsorption to iron oxides/oxyhydroxides 
$\left(\mathrm{Fe}_{\mathrm{ox}}\right)$ under weakly oxic conditions results in a variable fractionation $\left(\Delta^{98} \mathrm{Mo}=\delta^{98} \mathrm{Mo}_{\text {seawater }}-\right.$ $\delta^{98} \mathrm{Mo}_{\mathrm{Fe}-\mathrm{ox}}=0.83 \%$ to $2.19 \%$ ) (Goldberg et al., 2009). In euxinic waters, aqueous $\mathrm{H}_{2} \mathrm{~S}$ can effectively break the $\mathrm{Mo}=\mathrm{O}$ bond, transforming $\mathrm{MoO}_{4}^{2-}$ into oxythiomolybdate species $\left(\mathrm{MoO}_{4-x} \mathrm{~S}_{x}^{2-}, \mathrm{x}=1-4\right)$ (Helz et al., 1996). Under these conditions, Mo is actively scavenged into sediments at a rate that can be 100- to 1000-fold greater than that in oxic environments (Scott et al., 2008). Below a certain concentration of aqueous $\mathrm{H}_{2} \mathrm{~S}(\sim 11 \mu \mathrm{M})$ (Erickson and Helz, 2000), the Mo isotopic composition of the sediment is controlled by redox-related fractionation (Neubert et al., 2008). Above this $\left[\mathrm{H}_{2} \mathrm{~S}\right]_{\text {aq }}$ threshold, almost all molybdate is converted to tetrathiomolybdate $\left(\mathrm{MoS}_{4}^{2-}\right)$ and transferred quantitatively to the sediment via adsorption onto organic matter or incorporation into Fe-S-Mo nanoparticles (Algeo and Lyons, 2006; Helz et al., 2011), yielding a sediment Mo isotopic composition equal to that of the seawater source.

$\mathrm{MoO}_{4}^{2-}$ shows an affinity for $\mathrm{Fe}-\mathrm{Mn}$ oxyhydroxides $\left(\mathrm{Fe}-\mathrm{Mn}_{\mathrm{ox}}\right)$ possible via forming polynuclear Mo oxides (Wasylenki et al., 2011), onto which it readily adsorbs and which can lead to accelerated removal of Mo to the sediment. As a result, ferromanganese sediments (i.e. nodules, crusts and red clays etc.) on the abyssal seafloor show Mo enrichments to 100s of ppm (Morford and Emerson, 1999), accounting for $\sim 35-50 \%$ of the modern seawater Mo sink flux (Scott et al., 2008; Kendall et al., 2009). $\mathrm{MoO}_{4}^{2-}$ also readily adsorbs onto $\mathrm{Fe}-\mathrm{Mn}_{\mathrm{ox}}$ particulates that originate as fluvial sediment or that form at the oxic/anoxic chemocline in redox-stratified water bodies through oxidation of upward diffusing $\mathrm{Fe}^{2+}{ }_{\text {(aq) }}$ and $\mathrm{Mn}^{2+}$ (aq) (Algeo and Tribovillard, 2009; Scholz et al., 2013). The sinking Fe-Mn particulates transfer adsorbed Mo into anoxic waters below the chemocline, creating a "Fe-Mn shuttle". Mo is subsequently released through reductive dissolution, leading either to an aqueous Mo maximum just below the chemocline (Shimmield and Price, 1986) or to elevated Mo concentrations in sediment porewaters if Fe-Mn particulates reach the sediment-water interface before dissolving (Morford et al., 2005). In the latter case, part of the released Mo may diffuse back into the overlying water column, but also a fraction is generally taken up by the sulfidic sediment (Morford and Emerson, 1999; Scott and Lyons, 2012; Dahl et al., 2013). The degree of redox variability of a given environment and the vertical stability of the chemocline strongly influence the operation of an Fe-Mn shuttle (Algeo and Tribovillard, 2009). 


\section{GEOLOGICAL SETTING}

The Nanhua Basin formed through rifting at $\sim 820 \mathrm{Ma}$, or possibly earlier, during breakup of the Rodinia supercontinent (Wang and Li, 2003; Peng et al., 2012), and it evolved into a failed intracratonic rift basin by the Ediacaran (Fig. 1A) (Jiang et al., 2003; Li et al., 2008). Paleogeographic reconstructions for the early Cambrian show shallow platform, slope, and basin environments along a northwest-southeast transect based on lithological change from shallow carbonates to basinal black shales or mudstones during the Fortunian (Fig. 1B) (Goldberg et al., 2007). Widely deposited black shales of the basal Niutitang Formation may record a global transgression in the early Cambrian (Wang et al., 1998; Zhu et al., 2003; Miller et al., 2006).

The Yangjiaping section is located in Yangjiaping village, Shimen County, northwestern Hunan Province. At Yangjiaping, the Niutitang Formation comprises, in ascending order: (1) basal beds including $\sim 2.25 \mathrm{~m}$ of carbonaceous shale, $<1 \mathrm{~m}$ of phosphatic sediment, and $\sim 7 \mathrm{~m}$ of silty shale (not included in the present study); (2) a 18-m-thick black shale (lower member; LM); and (3) a $\geq 56$-m-thick gray silty shale (upper member; UM) (Fig. 1C). The lithological change in UM relative to LM apparently suggests a following marine regression in the basin. The Ni-Mo polymetallic layer at the base of the LM (not exposed at Yangjiaping) is an important marker horizon for stratigraphic correlation across the Nanhua Basin (Och et al., 2013). SHRIMP zircon U-Pb dating of an ash bed below the Ni-Mo layer yielded ages of $532.3 \pm 0.7 \mathrm{Ma}$ (Zunyi section, Guizhou Province; Jiang et al., 2009), 536.3 \pm 5.5 Ma (Ganziping section, Hunan Province; Chen et al., 2009), and 526.4 55.4 Ma (Three Gorges section, Hubei Province; Okada et al., 2014) (Fig. 1C). Re-Os isotopic dating of the Ni-Mo polymetallic layer gave an age of 521 \pm 5 Ma (Dazhuliushui and Maluhe sections in Guizhou Province and Sancha section in Hunan Province; Xu et al., 2011). The base of the LM of the Niutitang Formation thus dates to >521 Ma.

The Meishucunian Stage of the lower Cambrian in South China (equivalent to the Fortunian Stage and Stage 2 of the global Terreneuvian Series) is characterized by the appearance of four small shelly fossil assemblages (SSF 1-4), which can serve as important regional and intercontinental marker beds (Xiao et al., 2005; Steiner et al., 2007). SSF1, whose occurrence defines the Neoproterozoic-Cambrian boundary (Zhu et al., 2001), has been found within the 
2.25-m-thick carbonaceous shale of the basal beds at Yangjiaping (Fig. 1B) (Steiner et al., 2004). Higher in the Yangjiaping section, silty shales at $\sim 110 \mathrm{~m}$ yielded fragments of trilobites such as Hunanocephalus sp. that first appeared at 521-514 Ma, during the Qiongzhusian Stage of the lower Cambrian in South China (equivalent to Stage 3 of the global Series 2; Fig. 1C) (Yin et al., 1999), constraining the age of the upper part of the UM of the Niutitang Formation. In combination with the radiometric ages above, the study interval (i.e., the LM and UM of the Niutitang Formation at Yangjiaping) can most likely be assigned to global Cambrian stages 2-3 (529-514 Ma; Fig. 1C) (Cohen et al., 2013; updated).

\section{SAMPLES AND METHODS}

A total of 45 samples from the LM (20 samples) and UM (25 samples) of the Niutitang Formation in the Yangjiaping section, which were previously analyzed for sedimentary $\mathrm{Fe}$ speciation, Mo abundance, total organic matter (TOC), and pyrite S isotopes by Feng et al. (2014), were used in this study for further geochemical analyses. These samples were collected from the freshest rock exposures and samples that contain readily visible pyrite nodules or bands were discarded prior to crushing to minimize the inclusion of materials impacted most severely by later diagenesis (Feng et al., 2014). Sample powders were first ashed for $\sim 8 \mathrm{~h}$ at $600^{\circ} \mathrm{C}$ in a muffle furnace to remove organic matter. Of the 45 samples, 16 that were inferred to have been deposited in a euxinic environment were selected for analysis of Mo isotopes and trace element (U, V) abundances.

For trace-element analysis, $50 \mathrm{mg}$ of ashed powder were weighed into a Teflon beaker and dissolved using a standard $\mathrm{HF}-\mathrm{HNO}_{3}-\mathrm{HCl}$ protocol at a high temperature $\left(190^{\circ} \mathrm{C}\right)$. All trace elements were analyzed by inductivity coupled plasma mass spectrometry (ICP-MS) (Agilent 7700) at the State Key Laboratory of Biogeology and Environmental Geology, China University of Geosciences (Wuhan). Internal reference standards BHVO-2 and BCR-2 were analyzed simultaneously to monitor data quality. Accuracy is better than $10 \%$ and the analytical precision is $\sim 0.5 \%$ of reported values. Enrichment factors (EFs) for trace elements were calculated as:

$$
\mathrm{X}_{\mathrm{EF}}=(\mathrm{X} / \mathrm{Al})_{\mathrm{sample}} /(\mathrm{X} / \mathrm{Al})_{\mathrm{AUCC}}
$$


where $\mathrm{X}$ is the element of interest (e.g., Mo), and AUCC is average upper continental crust (McLennan, 2001). For correlative sections without published Al concentration data, $\mathrm{Zr}$, Ti or Sc was used for normalization instead.

A procedure similar to that described in Zhou et al. (2015) was used for Mo isotope analysis. Depending on the Mo concentration of a sample, from 10 to $50 \mathrm{mg}$ of powder was weighed out. A ${ }^{97} \mathrm{Mo}^{-100} \mathrm{Mo}$ double spike, which was calculated based on the Mo concentration and sample mass, was added to the sample, which was then digested using the same procedure as for trace-element analysis. The Mo content of the sample was purified in two steps: the anion resin GPM-1M (Bio-Rad) was first used to separate Mo and most Fe from the matrix, and the cation exchange resin AG50W-X8 (Bio-Rad) was then used to separate Mo from the remaining Fe and Zr. Mo isotope measurements were performed using a Neptune plus MC-ICP-MS instrument (Thermo Fisher Scientific) at the State Key Laboratory of Geological Process and Mineral Resources, China University of Geosciences (Wuhan). Results are reported using $\delta$ notation in per mil relative to the Johnson Matthey Company (JMC) Specpure Mo plasma standard (lot 602332B):

$$
\delta^{98} \mathrm{Mo}=\left(\left({ }^{98} \mathrm{Mo} /{ }^{95} \mathrm{Mo}\right)_{\text {sample }} /\left({ }^{98} \mathrm{Mo} /{ }^{95} \mathrm{Mo}\right)_{\mathrm{JMC}}-1\right) \times 1000 \%
$$

Relative to JMC standard, NIST SRM 3134, which is appealed as the international standard, has a value of $+0.27 \pm 0.06 \%$ (Goldberg et al., 2013; Nägler et al., 2013). Using the JMC standard, the Mo isotopic compositions of modern seawater and the international standard SDO-1 (Devonian Ohio Shale) are $+2.3 \%$ and $+1.10 \%$, respectively. The reproducibility of the measured $\delta^{98} \mathrm{Mo}$ ratios is better than $0.07 \%$. The long-term external reproducibility for the replicate measurements of the standard reference materials is better than $0.05 \%$.

To correct for minor amounts of terrigenously sourced Mo, the isotopic composition of the authigenic Mo fraction $\left(\delta^{98} \mathrm{Mo}_{\text {auth }}\right)$ was calculated using $\mathrm{Mo}=1.5 \mathrm{ppm}, \mathrm{Al}=8.04 \%$, and $\delta^{98} \mathrm{Mo}=$ $+0.36 \%$ as the parameters for the AUCC endmember (McLennan, 2001; Dahl et al., 2011). Calculated $\delta^{98} \mathrm{Mo}_{\text {auth }}$ values are close to measured $\delta^{98} \mathrm{Mo}$ values $\left(\delta^{98} \mathrm{Mo}_{\text {auth }}=1.0138 \times \delta^{98} \mathrm{Mo}+\right.$ $\left.0.016 ; \mathrm{R}^{2}=0.995 ; \mathrm{n}=16, \mathrm{p}(\alpha)<0.001\right)$ because terrigenous Mo comprises only a small fraction of total Mo in most samples $(3.6 \pm 4.0 \%)$. Only the $\delta^{98} \mathrm{Mo}_{\text {auth }}$ results are discussed below, and henceforth $\delta^{98}$ Mo refers to $\delta^{98} \mathrm{Mo}_{\text {auth }}$. 


\section{RESULTS}

The $\delta^{98}$ Mo results and other geochemical data for the study are given in Appendix Table A and shown in Figure 2. The black shales of the LM show fluctuating $\delta^{98}$ Mo values between $-0.65 \%$ and $+2.14 \%$, whereas the gray silty shales of the UM yield more uniform $\delta^{98}$ Mo values of $+1.16 \%$ to $+1.71 \%$ (Fig. 2). The Mo isotopic data from the Yangiiaping section are scattered over almost the entire range of reported $\delta^{98}$ Mo values from modern sediments (ca. $-0.7 \%$ to $+2.3 \%$ ), and they show no relationship to Mo concentrations $\left(\mathrm{R}^{2}=0.00\right.$, not shown). However, most samples (11 of 16) yield $\delta^{98}$ Mo values between $+1.0 \%$ and $+1.7 \%$, with only one sample $>2.0 \%$ and two samples $<0 \%$.

RSTEs are enriched throughout the study section, although the degree of enrichment is greater in the $\mathrm{LM}\left(\mathrm{Mo}_{\mathrm{EF}}=74-526, \mathrm{U}_{\mathrm{EF}}=16-68\right.$, and $\left.\mathrm{V}_{\mathrm{EF}}=6-76\right)$ than in the $\mathrm{UM}\left(\mathrm{Mo}_{\mathrm{EF}}=8-44\right.$, $\mathrm{U}_{\mathrm{EF}}=2-8$, and $\mathrm{V}_{\mathrm{EF}}=1-7$ ) (Fig. 2). Mn enrichments contrast with those of Mo, $\mathrm{U}$ and $\mathrm{V}$, showing higher values in the UM than in the LM (Fig. 2).

\section{DISCUSSION}

Sedimentary $\delta^{98} \mathrm{Mo}$ is controlled by local watermass redox conditions, basinal restriction, and mean global oceanic oxygenation status. Below, we will discuss each of these mechanisms separately to explore possible cause(s) for patterns of $\delta^{98}$ Mo variation in the Yangjiaping section and for the early Cambrian Nanhua Basin as a whole.

\subsection{Marine redox conditions at Yangjiaping}

Mo behavior and accompanying isotopic fractionations in the ocean are mainly controlled by marine redox conditions. Iron speciation and RSTE (Mo, U, V) enrichment are used here as proxies for local water-column redox conditions. Generally, a ratio of highly reactive iron to total iron $\left(\mathrm{Fe}_{\mathrm{HR}} / \mathrm{Fe}_{\mathrm{T}}\right)$ of $>0.38$ indicates anoxic conditions, with pyrite-to-highly-reactive-iron ratios $\left(\mathrm{Fe}_{\mathrm{py}} / \mathrm{Fe}_{\mathrm{HR}}\right)$ of $<0.7$ and $>0.7$ distinguishing between ferruginous and euxinic environments, 
respectively (Raiswell and Canfield, 2012). Uranium behaves conservatively in oxic waters but is taken up rapidly by the sediment at Fe reducing conditions (Tribovillard et al., 2006). Vanadium is reduced in a stepwise manner, from $\mathrm{V}^{5+}$ to $\mathrm{V}^{4+}$ under mildly reducing conditions and to $\mathrm{V}^{3+}$ under euxinic conditions, resulting in significant enrichment in anoxic systems (Algeo and Maynard, 2004; Tribovillard et al., 2006). High enrichments of these RSTEs (see Section 2 for a description of Mo enrichment) indicate deposition of sediment in a persistently euxinic environment, i.e., with a stable chemocline within the water column.

The lower LM (LM-1, 0-8.8 m) yields low $\mathrm{Fe}_{\mathrm{T}}(0.2-0.6 \%$, average $0.4 \%)$, which is comparable to the analytical error of $0.2 \%$ in Fe speciation analysis, making redox interpretations based on iron ratios less secure (Clarkson et al., 2014). $\mathrm{Fe}_{\mathrm{T}}$ concentrations show an abrupt increase to $4.4 \%$ at $9.3 \mathrm{~m}$ and a gradual decrease back to $<1 \%$ upsection. In this interval (LM-2, 9.3-16.3 m), $\mathrm{Fe}_{\mathrm{HR}}$ and $\mathrm{Fe}_{\mathrm{T}}$ exhibit a good correlation $\left(\mathrm{R}^{2}=0.99, \mathrm{p}(\alpha)<0.01\right)$ with an average $\mathrm{Fe}_{\mathrm{HR}} / \mathrm{Fe}_{\mathrm{T}}$ ratio of 0.75 , indicating that total $\mathrm{Fe}$ is dominated by the highly reactive iron fraction. The Fe peak at $9.3 \mathrm{~m}$ may represent remobilized Fe from oxic shallow-shelf areas or inputs of Fe-bearing water from a deep ferruginous basin via a marine transgression or upwelling event (Raiswell and Canfield, 2012). The upsection decrease in $\mathrm{Fe}_{\mathrm{T}}$ above $9.3 \mathrm{~m}$ was accompanied by an increase in $\mathrm{Fe}_{\mathrm{py}} / \mathrm{Fe}_{\mathrm{HR}}$ from mostly $<0.7$ to $>0.7$, indicating a transition from ferruginous to euxinic conditions that was probably caused by decreased Fe inputs. The sample YB18 at $14.8 \mathrm{~m}$ contains almost no $\mathrm{Fe}_{\mathrm{py}}$ but high $\mathrm{Fe}_{\mathrm{ox}}$ which is explained by Feng et al. (2014) as a result of modern oxidative weathering of pyrite in this sample. Both LM-1 and LM-2 show high enrichments in Mo $\left(\mathrm{Mo}_{\mathrm{EF}}=\right.$ 74-526, average 222 for LM-1 and 133-215, average 165 for LM-2), $\mathrm{U}\left(\mathrm{U}_{\mathrm{EF}}=24-68\right.$, average 42 for LM-1 and 16-30, average 23 for LM-2) and $\mathrm{V}\left(\mathrm{V}_{\mathrm{EF}}=11-198\right.$, average 58 for LM-1 and 7-20, average 11 for LM-2), indicating strongly euxinic depositional conditions for most samples. LM-2 exhibits a weak decrease in RSTE enrichment relative to LM-1, which was possibly related to a transient shift from euxinic to ferruginous conditions due to the iron pulse that peaked at $9.3 \mathrm{~m}$. In summary, LM-1 accumulated under persistently euxinic, Fe-limited conditions, whereas LM-2 records ferruginous conditions at its base caused by an Fe pulse, followed by a transition to euxinic conditions upsection.

The gray silty shales of the UM contain $>1 \% \mathrm{Fe}_{\mathrm{T}}(1.2-4.1 \%$, average $2.6 \%)$, allowing local 
redox conditions to be evaluated on the basis of iron speciation data (Fig. 2). $\mathrm{Fe}_{\mathrm{HR}} / \mathrm{Fe}_{\mathrm{T}}$ ranges from 0.08 to 0.58 with an average of $0.34 \pm 0.14$, whereas $\mathrm{Fe}_{\mathrm{py}} / \mathrm{Fe}_{\mathrm{HR}}$ ranges from 0 to 0.91 with an average of $0.46 \pm 0.35$. This combination of iron ratios suggests deposition under fluctuating, weakly oxic (where Mn oxides precipitate) to anoxic-ferruginous bottomwater conditions with occasional episodes of weak euxinia. RSTE concentrations for the UM support this interpretation. Mo removal under weakly oxic conditions is less efficient than under euxinic conditions (Scott and Lyons, 2012), and the modest enrichment of Mo in the $\mathrm{UM}\left(\mathrm{Mo}_{\mathrm{EF}}=6-76\right.$, mean 25; Fig. 2$)$ is consistent with the occasional presence of $\mathrm{H}_{2} \mathrm{~S}$ in bottom waters but excludes persistently euxinic conditions. Mo probably accumulated in the $\mathrm{UM}$ either through adsorption onto $\mathrm{Mn}-\mathrm{Fe}_{\mathrm{ox}}$ particulates in the water column (Dellwig et al., 2010) or through uptake from Mo-limited sulfidic sediment porewaters (Scott and Lyons, 2012). In addition, U and V show minimal enrichments $\left(\mathrm{U}_{\mathrm{EF}}=4 \pm 2 ; \mathrm{V}_{\mathrm{EF}}=3 \pm 2\right)$, which are also consistent with weakly oxic to anoxic-ferruginous conditions of deposition. Redox fluctuations during deposition of the UM may reflect vertical movements of the $\mathrm{O}_{2} / \mathrm{H}_{2} \mathrm{~S}$ chemocline across the sediment-water interface.

The gradual decline in Mo, $\mathrm{U}$ and $\mathrm{V}$ enrichments upsection (Fig. 2) suggests that the average position of the $\mathrm{O}_{2} / \mathrm{H}_{2} \mathrm{~S}$ chemocline gradually shifted from within the water column during LM deposition to close to the sediment-water interface during deposition of the lower UM, and then downward into the sediment during deposition of the upper UM. For this reason, only the euxinic sediments in the LM offer a potential record of contemporaneous seawater $\delta^{98} \mathrm{Mo}$, whereas local redox conditions were the dominant influence on $\delta^{98}$ Mo through the remainder of the section.

\subsection{Restriction of early Cambrian Nanhua Basin?}

Restriction of watermass exchange with the open ocean can limit Mo availability in cratonic basins and influence Mo isotopic fractionations during authigenic uptake by the sediment. Several lines of evidence indicate that the early Cambrian Nanhua Basin had good connection with open ocean. First, global paleogeographic reconstructions for the early Cambrian show South China as an isolated continent surrounded by the open ocean (Fig. 1A) (Li et al., 2008). Second, detailed regional stratigraphic studies have documented that water depths gradually increased to the 
southeast from the Yangtze Platform into the deep Nanhua Basin (Fig. 1B) (Zhu et al., 2003; Jiang et al., 2011; Zhu et al., 2013; Jin et al., 2014). However, the amalgamation history between the Yangtze and Cathaysia blocks is still under debate ( $\mathrm{Li}$ et al., 2009). Thus, the effect of the Cathaysia Block on restriction of the Nanhua Basin in the early Cambrian is impossible to evaluate with current information. Third, the same small shelly fossils (SSFs) found on the Yangtze Platform are present nearly worldwide (including the West Gondwana blocks, Siberia, Newfoundland, and Australia) (Steiner et al., 2007), which suggests unfettered movement of the shell producers among open-ocean sites. Finally, the carbonate carbon isotope profiles of lower Cambrian sections from the Yangtze Platform have been globally correlated (Komura and Watanabe, 2001; Jiang et al., 2007; Wang et al., 2012; Li et al., 2013; Guo et al., 2014), demonstrating a seawater carbonate chemistry similar to that of the global open ocean.

The degree of restriction of modern marine watermasses can be assessed based on bottomwater aqueous Mo concentrations ([Mo $]_{\mathrm{aq}}$ ), which are generally more depleted in silled basins. Algeo and Lyons (2006) demonstrated a range of sediment Mo/TOC ratios in modern silled marine basins, ranging from $\sim 4.5 \mathrm{ppm} / \mathrm{wt} \%$ for the Black Sea $\left([\mathrm{Mo}]_{\mathrm{aq}}=\sim 3-5 \mathrm{nM}\right)$ to $\sim 45$ $\mathrm{ppm} / \mathrm{wt} \%$ for Saanich Inlet $\left([\mathrm{Mo}]_{\mathrm{aq}}=\sim 90-110 \mathrm{nM}\right)$ (Fig. 3). These values correlate strongly with the degree of deepwater restriction as a consequence of basin-scale drawdown of aqueous Mo and other RSTEs through removal to the sediment with limited resupply. At Yangjiaping, the LM exhibits mean Mo/TOC ratios of $13 \pm 6 \mathrm{ppm} / \mathrm{wt} \%$, whereas the UM exhibits mean Mo/TOC ratios of $17 \pm 5 \mathrm{ppm} / \mathrm{wt} \%$. Assuming modern oceanic boundary conditions, Mo/TOC ratios of $\sim 13-17$ $\mathrm{ppm} / \mathrm{wt} \%$, as observed at Yangjiaping, would be equivalent to a moderate to strong degree of deepwater restriction (i.e., similar to the Cariaco Basin or Framvaren Fjord). However, this conjecture is at odds with our inference of free watermass exchange between the Nanhua Basin and the open ocean (see above).

This apparent contradiction can be resolved if global seawater Mo concentrations were lower during the early Cambrian than in modern seawater (Algeo, 2004). Similar or lower sediment $\mathrm{Mo} / \mathrm{TOC}$ ratios have been reported from lower Cambrian strata in Oman (5-22 ppm/wt\%, average $11 \pm 6 \mathrm{ppm} / \mathrm{wt} \%$ ) (Wille et al., 2008) and the Tarim Basin of China (1-17 ppm/wt\%, average $5 \pm 5$ ppm/wt\%) (Yu et al., 2009), suggesting that such values are representative of the early Cambrian 
global ocean in general, instead of a restricted-basin watermass. Sedimentary Mo/TOC ratios of $\sim 13-17 \mathrm{ppm} / \mathrm{wt} \%$ at Yangjiaping are roughly equivalent to an aqueous Mo concentration of $\sim 30-45$ nM (Algeo and Rowe, 2012, their figure 3A), which, if representative of the early Cambrian global ocean, indicates that contemporaneous seawater Mo concentrations were less than half of their modern level. However, this estimate represents a minimum value based on the inference of full watermass exchange between the Nanhua Basin and early Cambrian global ocean, whereas an assumption of partial restriction of the Nanhua Basin (which potentially is possible) would yield seawater Mo estimates between the $\sim 30-45 \mathrm{nM}$ minimum and the $104 \mathrm{nM}$ modern seawater Mo concentration. It should be noted that, even at the minimum concentration, the residence time of Mo in the early Cambrian ocean would have been much longer (>100 kyr) than the seawater mixing time, yielding a homogeneous seawater Mo isotope composition in the global ocean.

We should note that the difference between the mean Mo/TOC ratios of the LM $(13 \pm 6$ $\mathrm{ppm} / \mathrm{wt} \%)$ and $\mathrm{UM}(17 \pm 5 \mathrm{ppm} / \mathrm{wt} \%)$ is not statistically significant. Compilation of data for stratigraphic equivalents of the Niutitang Formation representing a range of paleo-water depths in the Nanhua Basin shows only limited variation in Mo/TOC ratios, with an average of 11 (6-19) $\mathrm{ppm} / \mathrm{wt} \%(\mathrm{n}=238)$ [i.e., median $\left(16^{\text {th }}-84^{\text {th }}\right.$ percentile range $)$ ] (Fig. 3$)$, implying that aqueous Mo concentrations were relatively uniform throughout the basin. The similarity of Mo/TOC ratios for Yangjiaping and other lower Cambrian sections of the Nanhua Basin suggests that no significant topographic barriers existed within the basin. At the same time, due to the good connection between the Nanhua Basin and the open ocean, basin restriction would have had very limited effect on the Mo isotopic compositions in the Nanhua Basin watermass.

\subsection{Interpretation of Mo isotopic records at Yangjiaping}

\subsubsection{LM: fluctuating $\mathrm{H}_{2} \mathrm{~S}$ concentrations}

Two LM samples with intermediate $\delta^{98}$ Mo values $(+0.89 \%$ for YB11 and $+1.34 \%$ or YB14) were deposited in ferruginous waters, possibly reflecting a fractionation caused by Mo adsorption onto $\mathrm{Fe}-\mathrm{Mn}_{\mathrm{ox}}$. This interpretation is supported by the higher $\mathrm{Fe}_{\mathrm{ox}}$ concentrations of these samples 
$(1.0-1.6 \%)$ than in other LM samples $(<0.4 \%$, except YB-18 which was altered by modern pyrite oxidation; Feng et al., 2014). The remaining LM samples $(\mathrm{n}=8)$, which represent euxinic sediments, have Mo isotopic compositions ranging from $-0.65 \%$ to $+2.14 \%$. Several considerations argue against these values being a record of contemporaneous seawater $\delta^{98}$ Mo. First, because no known process removes Mo to the sediment that is isotopically heavier than seawater Mo, the $\delta^{98}$ Mo of seawater cannot be lower than that of its source (Wille et al., 2008). For this reason, the negative values of $-0.65 \%$ and $-0.27 \%$ in the LM cannot represent seawater $\delta^{98} \mathrm{Mo}$ because they are lower than the isotopic composition of the upper continental crust

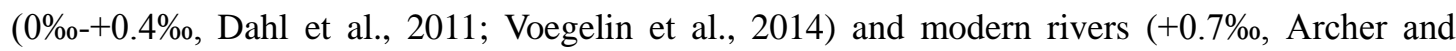
Vance, 2008). Secondly, variation in seawater $\delta^{98}$ Mo will accompany changes in the Mo reservoir size (Wille et al., 2008; Dahl et al., 2010). The observation that Mo and other RSTEs show high and relatively stable concentrations in the LM implies no significant changes in the global seawater Mo reservoir size or the basin-ocean connection (see Section 6.2) and, thus, little or no change in contemporaneous seawater $\delta^{98}$ Mo. Therefore, the wide range in $\delta^{98}$ Mo of LM samples $\left(-0.65 \%\right.$ to $+2.14 \%$ ) is unlikely to represent variations in seawater $\delta^{98} \mathrm{Mo}$.

The most likely control on $\delta^{98}$ Mo of the LM at Yangjiaping was local watermass redox conditions, specifically, aqueous $\mathrm{H}_{2} \mathrm{~S}$ concentrations. Under euxinic conditions, high $\left[\mathrm{H}_{2} \mathrm{~S}\right]_{\text {aq }}(>11$ $\mu \mathrm{M})$ leads to quantitative conversion of $\mathrm{MoO}_{4}^{2-}$ to $\mathrm{MoS}_{4}^{2-}$ without significant isotopic fractionation, but low $\left[\mathrm{H}_{2} \mathrm{~S}\right]_{\text {aq }}(<11 \mu \mathrm{M})$ leads to only partial, transient (on a scale of years, depending on the $\mathrm{pH}$ ) conversion to $\mathrm{MoS}_{4}^{2-}$ with variable Mo isotope fractionations (Helz et al., 1996; Erickson and Helz, 2000; Poulson et al., 2006). In the latter circumstance, a positive linear relation exists in the modern Black Sea between $\left[\mathrm{H}_{2} \mathrm{~S}\right]_{\mathrm{aq}}$ and sediment $\delta^{98} \mathrm{Mo}$, making the latter a possible proxy for the former in ancient seawater (Arnold et al., 2012). Given continuously euxinic conditions during deposition of LM-1 (see Section 6.1), we infer that the wide range of $\delta^{98}$ Mo values (Fig. 2) reflects low $(<11 \mu \mathrm{M})$ and variable $\left[\mathrm{H}_{2} \mathrm{~S}\right]_{\mathrm{aq}}$ during their deposition. For these samples, the highest $\delta^{98} \mathrm{Mo}$ value represents the largest $\left[\mathrm{H}_{2} \mathrm{~S}\right]_{\text {aq }}$ (i.e., approaching $11 \mu \mathrm{M}$ ) and the minimum Mo-isotope fractionation (i.e., approaching $0 \%$ ), whereas the lowest $\delta^{98}$ Mo value represents the smallest $\left[\mathrm{H}_{2} \mathrm{~S}\right]_{\mathrm{aq}}$ and maximum Mo-isotope fractionation relative to contemporaneous seawater. 
Low $\left[\mathrm{H}_{2} \mathrm{~S}\right]_{\mathrm{aq}}$ may have been prevalent in euxinic waters throughout the early Cambrian Nanhua Basin. To test this hypothesis, we compiled all published $\delta^{98}$ Mo data from lower Cambrian units (roughly 529-514 Ma) of the Nanhua Basin ( $\mathrm{n}=155$, representing 5 sections). We focused our analysis on a subset of 118 samples of fine-grained siliciclastic rocks having $\mathrm{Fe}$ speciation and Mo concentration data, permitting assessment of local depositional redox conditions. Of these 118 samples, 52 have $\mathrm{Fe}_{\mathrm{HR}} / \mathrm{Fe}_{\mathrm{T}}$ ratios and Mo concentrations indicative of euxinic depositional conditions. The $\delta^{98} \mathrm{Mo}$ of this subset ranges from $-0.7 \%$ to $+2.3 \%$. Persistently high $\delta^{98}$ Mo values of ca. $+2.3 \%$ in euxinic shales of the Yu'anshan member at Meishucun (Wen et al., 2011; Wen et al., 2015), which is a secondary stratotype section correlative with Yangjiaping (Zhu et al., 2003; Jin et al., 2014; Jin et al., 2016), have been argued to represent early Cambrian seawater $\delta^{98}$ Mo (Chen et al., 2015). If so, then most samples of the LM in the Yangjiaping section must have been deposited in bottomwaters with $\left[\mathrm{H}_{2} \mathrm{~S}\right]_{\mathrm{aq}}<11 \mu \mathrm{M}$. Furthermore, only $\sim 3.8 \%$ ( 2 of 52 ) of all the euxinic samples in our Nanhua Basin compilation dataset have $\delta^{98}$ Mo higher than $+2.0 \%$ (Fig. 4) and, thus, potentially record the contemporaneous seawater $\delta^{98}$ Mo signal. This observation suggests that euxinic waters within the early Cambrian Nanhua Basin were generally characterized by low $\left[\mathrm{H}_{2} \mathrm{~S}\right]_{\text {aq }}$ (i.e., $<11 \mu \mathrm{M}$ ). Seawater $\mathrm{H}_{2} \mathrm{~S}$ concentrations are controlled by sulfate reservoir size, and sulfate concentrations in early Cambrian oceans may have been $\sim 2 \mathrm{mM}$ or less, i.e., much lower than in the modern ocean (28 mM) (Loyd et al., 2012; Feng et al., 2014; Algeo et al., 2015). Low seawater sulfate concentrations, with given iron fluxes and marine productivity, were probably key factors in sustaining $\left[\mathrm{H}_{2} \mathrm{~S}\right]_{\text {aq }}$ below $11 \mu \mathrm{M}$ in the early Cambrian Nanhua Basin.

\subsubsection{UM: Fe-Mn shuttle effects}

Manganese behavior in the LM versus the UM of the Niutitang Formation is markedly different. Although all samples show $\mathrm{Mn}_{\mathrm{EF}}<1.0$ (Fig. 2), indicating a Mn deficit relative to the upper continental crust, Mn concentrations are less depleted in the UM relative to the LM (see Appendix Table A), and a good linear relationship is observed between Mn and Fe concentrations in the $\mathrm{UM}\left(\mathrm{R}^{2}=0.83, \mathrm{p}(\alpha)<0.01\right)$ but not in the $\mathrm{LM}\left(\mathrm{R}^{2}=0.19\right)$ (Fig. 5A). These patterns are 
consistent with Mn-Fe behavior in modern stratified basins such as the Black Sea, Baltic Sea, and Oslo Fjord, in which reduction of $\mathrm{Mn}(\mathrm{IV})$ to $\mathrm{Mn}$ (II) and $\mathrm{Fe}(\mathrm{III})$ to $\mathrm{Fe}(\mathrm{II})$ around the $\mathrm{O}_{2} / \mathrm{Mn}^{2+}-\mathrm{Fe}^{2+}$ chemocline can result in remobilization of these elements from the sediment (Trouwborst et al., 2006). Further, dissolved Fe/Mn ratios in these systems are constant in oxic and weakly oxic waters due to their similar behaviors but decrease significantly in euxinic environments due to sequestration of Fe in pyrite (Pakhomova and Yakushev, 2011). These processes can account for (1) the deficit of Mn in both the LM and UM relative to the upper continental crust due to its reduction, (2) the greater depletion of the LM relative to the UM, owing to the more reducing conditions of the former, and (3) the linear relationship between Mn and Fe concentrations in the UM but not the LM, owing to variable sequestration of $\mathrm{Fe}$ in pyrite of the latter. The observed Mn-Fe concentration patterns are consistent with our inference that the $\mathrm{O}_{2} / \mathrm{H}_{2} \mathrm{~S}$ chemocline shifted from the water column to the sediment-water interface during the transition from the LM to the UM of the Niutitang Formation.

Precipitation and reduction of Fe- $\mathrm{Mn}_{\mathrm{ox}}$ may have significantly influenced levels of authigenic Mo enrichment due to the strong adsorption of Mo onto Fe- $\mathrm{Mn}_{\mathrm{ox}}$. As adsorption of $\mathrm{U}$ onto $\mathrm{Fe}-\mathrm{Mn}_{\mathrm{ox}}$ is limited, authigenic Mo enrichment can substantially exceed that of $\mathrm{U}$ when a local $\mathrm{Fe}-\mathrm{Mn}_{\text {ox }}$ particulate shuttle is active in the water column or at the sediment-water interface (Algeo and Tribovillard, 2009). At Yangjiaping, LM samples exhibit large $\mathrm{Mo}_{\mathrm{EF}}$ and $\mathrm{U}_{\mathrm{EF}}$ as well as Mo/U ratios of 1-3 times that of modern seawater, reflecting sediment uptake of RSTEs from a euxinic water column (Fig. 5B; see Section 6.1). In contrast, the UM exhibits only modest enrichments of RSTEs, with lower concentrations of Mo and, especially, U, consistent with less reducing watermass conditions than for the LM. UM samples also show elevated Mo/U ratios relative to the open-marine trend (Fig. 5B) (Algeo and Tribovillard, 2009), which suggests operation of a local $\mathrm{Fe}-\mathrm{Mn}_{\mathrm{ox}}$ particulate shuttle. $\mathrm{Fe}-\mathrm{Mn}_{\mathrm{ox}}$ particulate shuttles are generally found only in stratified basins in modern oceans due to the need for a redox gradient, and they are most effective at transferring Mo to the sediment in systems with fluctuating $\mathrm{O}_{2} / \mathrm{H}_{2} \mathrm{~S}$ chemoclines, as in the modern Baltic Sea (Dellwig et al., 2010; Scholz et al., 2013) and Saanich Inlet (Berrang and Grill, 1974; Francois, 1988).

As $\mathrm{Fe}-\mathrm{Mn}_{\mathrm{ox}}$ adsorption preferentially takes up isotopically light Mo, the operation of an 
Fe-Mn ${ }_{\text {ox }}$ shuttle will shift authigenic Mo toward lower Mo isotopic compositions. In the modern Cariaco Basin, which is characterized by weakly euxinic waters and an active $\mathrm{Fe}-\mathrm{Mn}_{\mathrm{ox}}$ shuttle, bulk sediment $\delta^{98}$ Mo is $\sim 0.5 \%$ lighter than seawater $\delta^{98}$ Mo (Arnold et al., 2004). Similarly, the $\mathrm{UM}$ at Yangjiaping shows intermediate $\delta^{98}$ Mo values (from $+1.16 \%$ to $+1.71 \%$, mean $+1.52 \%$; Fig. 2) that are similarly lower than the inferred Mo isotopic composition of contemporaneous seawater. Fractionation caused by $\mathrm{Mn}_{\mathrm{ox}}$ adsorption is constant while that related to $\mathrm{Fe}_{\mathrm{ox}}$ adsorption depends on mineralogy (Barling and Anbar, 2004; Goldberg et al., 2009). The linear relationship between the $\mathrm{Mn}$ and $\mathrm{Fe}$ concentrations in the UM (Fig. 5A) indicates relatively constant $\mathrm{Mn} / \mathrm{Fe}$ ratio and $\mathrm{Fe}$ mineralogical composition in water columns, which may explain the relatively uniform $\delta^{98}$ Mo values of the UM.

Whether an $\mathrm{Fe}-\mathrm{Mn}_{\mathrm{ox}}$ particulate shuttle operated broadly within the early Cambrian Nanhua Basin has important implications for Mo biogeochemical cycling. Existing redox models for the basin invoke a dynamically maintained euxinic wedge at intermediate depths (Feng et al., 2014; Jin et al., 2016), on the margins of which an $\mathrm{Fe}-\mathrm{Mn}_{\mathrm{ox}}$ shuttle is likely to have operated, leading to significant Mo enrichments. The basinwide importance of $\mathrm{Fe}-\mathrm{Mn}_{\mathrm{ox}}$ shuttles can be assessed based on $\mathrm{Mo}_{\mathrm{EF}}-\mathrm{U}_{\mathrm{EF}}$ data ( $\mathrm{n}>200$ ) compiled for multiple lower Cambrian sections (Fig. 5B). Although the absolute $\mathrm{Mo}_{\mathrm{EF}}-\mathrm{U}_{\mathrm{EF}}$ values of modern marine systems (Algeo and Tribovillard, 2009) may not match those of the early Cambrian owing to the possibility of reduced seawater Mo mass in the latter, the general trends should be similar. The majority of data from the Nanhua Basin conform to the pattern of the modern open ocean, which is mainly controlled by bottom-water redox variation over a continuum from oxic to euxinic conditions (red arrow in Fig. 5B). This pattern is consistent with a dominant local redox control on Mo and $U$ enrichment in the Yangjiaping shales. However, a large subset of samples shows higher $\mathrm{Mo}_{\mathrm{EF}} / \mathrm{U}_{\mathrm{EF}}$, indicating local development of Fe-Mn ${ }_{\text {ox }}$ shuttles within the redox-stratified Nanhua Basin (Fig. 5B).

\subsection{Synthesis: Mo biogeochemistry in the early Cambrian Nanhua Basin and its broader implications}

Mo biogeochemical cycling in the early Cambrian Nanhua Basin took place in the context of 
a stratified oceanic redox structure, in which euxinia existed dynamically at intermediate depths, separating oxic shallow waters from ferruginous deep waters (Fig. 6; Li et al., 2010; Feng et al., 2014; Jin et al., 2016). Based on our interpretation of $\delta^{98}$ Mo data at Yangjiaping and other sections, we propose that an Fe- $\mathrm{Mn}_{\mathrm{ox}}$ reduction zone, similar to modern oxic/anoxic chemocline, may have developed just above the euxinic wedge due to sinking of $\mathrm{Fe}-\mathrm{Mn}_{\mathrm{ox}}$ particulates from the surface oxic waters ( $\mathrm{Li}$ et al., 2015). This $\mathrm{Fe}-\mathrm{Mn}_{\mathrm{ox}}$ reduction zone would have gradually attenuated

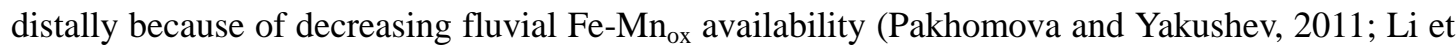
al., 2015). $\mathrm{H}_{2} \mathrm{~S}$ concentrations $\left(\left[\mathrm{H}_{2} \mathrm{~S}\right]_{\mathrm{aq}}\right)$ in the euxinic watermass, which were controlled by the relative availabilities of sulfate, reactive iron, and organic matter (Li et al., 2015), reached a peak within the euxinic wedge and decreased both shoreward and basinward (Fig. 6).

Within this model framework, all of the existing Mo isotopic data from lower Cambrian units of the Nanhua Basin can be explained. An Fe- $\mathrm{Mn}_{\mathrm{ox}}$ shuttle is likely to have operated in the nearshore $\mathrm{Fe}-\mathrm{Mn}_{\mathrm{ox}}$ reduction zone. There, isotopically light Mo was adsorbed in oxic surface waters and released in the $\mathrm{Fe}-\mathrm{Mn}_{\mathrm{ox}}$ reduction zone, after which it was rapidly scavenged by either sulfidic porewaters ("A" in Fig. 6) or a euxinic lower water column ("B" in Fig. 6) into the sediment, resulting in higher $\mathrm{Mo}_{\mathrm{EF}}$ relative to $\mathrm{U}_{\mathrm{EF}}$. Scenario A applies to the $\mathrm{UM}$ at Yangjiaping, which was deposited under mainly weakly oxic to anoxic-ferruginous conditions with only occasional episodes of weak euxinia (see Section 6.1) and exhibits a moderate Mo-isotopic fractionation $(\geq 0.62 \%)$. It should be noted that Mo behavior and isotopic fractionation in sediment porewaters remain poorly known (Scott and Lyons, 2012), which can potentially result in much more complicated Mo isotopic compositions. Furthermore, given ferruginous conditions in the deep basin, an Fe- $\mathrm{Mn}_{\mathrm{ox}}$ shuttle also may have likely operated at the boundary between distal oxic surface waters and ferruginous deep waters ("D" in Fig. 6). However, this Fe-Mn $\mathrm{ox}_{\mathrm{x}}$ shuttle may not have contributed much authigenic Mo to the sediment given the absence of sulfidic waters nearby.

Our model predicts strong spatial variation in sediment $\delta^{98}$ Mo values. Because of the compounded effects of Mo isotopic fractionation associated with low $\left[\mathrm{H}_{2} \mathrm{~S}\right]_{\mathrm{aq}}$ and $\mathrm{Fe}-\mathrm{Mn}_{\mathrm{ox}}$ adsorption, the most negative sediment $\delta^{98}$ Mo values are expected close to the boundary between the $\mathrm{Fe}-\mathrm{Mn}_{\mathrm{ox}}$ reduction zone and the euxinic wedge, where sediments can record $\delta^{98} \mathrm{Mo}$ with a fractionation of $>3 \%$ due to both the $\mathrm{Fe}-\mathrm{Mn}_{\mathrm{ox}}$ adsorption and the lowest $\left[\mathrm{H}_{2} \mathrm{~S}\right]_{\mathrm{aq}}$ in euxinic 
bottomwaters (Fig. 6). With increasing $\left[\mathrm{H}_{2} \mathrm{~S}\right]_{\mathrm{aq}}$ in deeper waters offshore, the Mo-isotopic fractionation associated with low $\left[\mathrm{H}_{2} \mathrm{~S}\right]_{\mathrm{aq}}$ will gradually diminish. Because the isotopic effect of Fe- $\mathrm{Mn}_{\mathrm{ox}}$ adsorption will also diminish offshore due to decreasing fluvial Fe-Mn $\mathrm{ox}_{\mathrm{ox}}$ availability, the highest sediment $\delta^{98} \mathrm{Mo}$ values - those closest to the $\delta^{98} \mathrm{Mo}$ composition of contemporaneous seawater-are expected in the area of maximum $\left[\mathrm{H}_{2} \mathrm{~S}\right]_{\mathrm{aq}}$ within the euxinic wedge ("C" in Fig. 6). Beyond this point to the basinward boundary of the euxinic wedge, sediment $\delta^{98}$ Mo values are predicted to decrease again owing to less-than-quantitative conversion to thiomolybdates and uptake of aqueous Mo under weakening euxinic conditions. However, negative Mo-isotopic fractionations as large as those in the nearshore $\mathrm{Fe}-\mathrm{Mn}_{\mathrm{ox}}$ reduction zone will not be achieved owing to decreasing $\mathrm{Fe}-\mathrm{Mn}_{\mathrm{ox}}$ availability and the weak isotopic effects of $\mathrm{Fe}-\mathrm{Mn}_{\mathrm{ox}}$ adsorption in the deep basin. The highly variable $\delta^{98}$ Mo values of LM black shales at Yangjiaping, as well as those from other euxinic facies in the late Neoproterozoic and early Cambrian Nanhua Basin (Lehmann et al., 2007; Wille et al., 2008; Xu et al., 2012; i.e., Kendall et al., 2015; Wen et al., 2015), conform well to the scenarios associated with a euxinic wedge (Fig. 6).

Mo absorbed by $\mathrm{Fe}-\mathrm{Mn}_{\mathrm{ox}}$ particulates can be reductively released and diffused back into the water column in the modern ocean (Morford et al., 2009). However, in a stratified early ocean with active $\mathrm{Fe}-\mathrm{Mn}_{\mathrm{ox}}$ shuttles, the burial flux of isotopically light Mo is likely to have been larger because (1) most of the Mo released by nearshore Fe-Mn ${ }_{\text {ox }}$ cycling would have been effectively taken up either in underlying sulfidic porewaters or the nearby euxinic wedge watermass (i.e., scenarios A and B in Fig. 6), and (2) the efficiency of Fe- $\mathrm{Mn}_{\mathrm{ox}}$ cycling may have been higher owing to a more pronounced redox gradient. For these reasons, the rate of authigenic Mo uptake may have been higher in early stratified oceans than in the modern. At the same time, most Mo removed to the sediment under euxinic conditions would have a $\delta^{98}$ Mo lower than that of contemporaneous seawater due to widely low $\mathrm{H}_{2} \mathrm{~S}$ concentrations. In theory, these two mechanisms might likely cause unusually heavy seawater $\delta^{98}$ Mo of the early oceans. Although quantitative estimation of the effects of these mechanisms is difficult, they should be considered in applying Mo-isotopic records to reconstruction of the redox state of early oceans. Furthermore, given that the stratified nature of early oceans has been widely recognized (see the review in Lyons et al., 2014), we suggest that the new Mo biogeochemical model proposed in this study for 
the early Cambrian Nanhua Basin may have broader applicability to basins of other locations and ages.

\section{CONCLUSIONS}

To explore the Mo biogeochemical cycle within a redox-stratified early ocean, we carried out a detailed Mo-isotopic study on shales of the lower Cambrian ( 529-514 Ma) Niutitang Formation in the shelf-margin Yangjiaping section, South China. Our key findings are:

(1) Black shales of the lower member (LM) of the Niutitang Formation were deposited under mainly euxinic conditions with episodes of ferruginous conditions due to pulsed inputs of reactive Fe. In contrast, gray silty shales of the upper member (UM) were deposited under conditions fluctuating from suboxia to weak euxinia.

(2) The LM shows $\delta^{98}$ Mo values ranging from $-0.65 \%$ to $+2.14 \%$. This variation mainly reflects low $(<11 \mu \mathrm{M})$, fluctuating $\left[\mathrm{H}_{2} \mathrm{~S}\right]_{\mathrm{aq}}$ in contemporaneous seawater. By compiling published $\delta^{98}$ Mo data from many age-roughly-equivalent sedimentary units in the early Cambrian Nanhua Basin, we found that only a small subset of euxinic samples recorded the Mo isotopic composition of contemporaneous seawater, indicating that seawater $\left[\mathrm{H}_{2} \mathrm{~S}\right]_{\mathrm{aq}}$ was generally low $(<11 \mu \mathrm{M})$ during this period.

(3) An Fe-Mn shuttle operated vigorously during deposition of the UM but only weakly or not at all during deposition of the LM at Yangjiaping. Limited $\delta^{98}$ Mo variation in the UM (from $+1.16 \%$ to $+1.71 \%$ ) and elevated Mo/U ratios reflect the combined effects of Mo adsorption onto Fe-Mn particulates and sulfidic porewaters.

(4) Variation of sediment $\delta^{98}$ Mo in lower Cambrian units of the Nanhua Basin can be explained by a new Mo biogeochemical model in which a nearshore Fe-Mn reduction zone developed between oxic surface waters and the mid-depth euxinic wedge. In this model, highly variable sediment $\delta^{98}$ Mo can be explained by combined fractionations associated with low $\left[\mathrm{H}_{2} \mathrm{~S}\right]_{\mathrm{aq}}$ and strong Mo adsorption onto $\mathrm{Fe}-\mathrm{Mn}_{\mathrm{ox}}$ associated with active Fe-Mn cycling. This model highlights the potential for compounded fractionation effects on sedimentary $\delta^{98}$ Mo records, and it may have broader implications for other 
early oceans possessing a similar stratified redox structure.

$21 / 30$ 


\section{ACKNOWLEDGMENTS}

We thank Gwyneth W. Gordon, Jian-Ming Zhu, Han-Jie Wen, Ting Zhang, Zhi-Fang Hu and Shi-Da Tang for laboratory assistance and manuscript improvement. This study was supported by the Chinese 973 program (grant No. 2013CB955704), the NSFC (grant No. 41172030) to CL and the 111 Project (grant No. B08030). TJA gratefully acknowledges support from the Sedimentary Geology and Paleobiology program of the U.S. National Science Foundation, the NASA Exobiology program, and the China University of Geosciences-Wuhan (programs GPMR201301 and BGL201407). LZ acknowledges support from NSFC (grant No. 41273005 and 41473007) and SJ acknowledges support from NSFC (grant No. 41230102). 


\section{REFERENCES}

Algeo, T.J. (2004) Can marine anoxic events draw down the trace element inventory of seawater? Geology 32, 1057-1060.

Algeo, T.J. and Maynard, J.B. (2004) Trace-element behavior and redox facies in core shales of Upper Pennsylvanian Kansas-type cyclothems. Chem. Geol. 206, 289-318.

Algeo, T.J. and Lyons, T.W. (2006) Mo-total organic carbon covariation in modern anoxic marine environments: Implications for analysis of paleoredox and paleohydrographic conditions. Paleoceanography 21, DOI: 10.1029/2004pa001112.

Algeo, T.J. and Tribovillard, N. (2009) Environmental analysis of paleoceanographic systems based on molybdenum-uranium covariation. Chem. Geol. 268, 211-225.

Algeo, T.J. and Rowe, H. (2012) Paleoceanographic applications of trace-metal concentration data. Chem. Geol. 324-325, 6-18.

Algeo, T.J., Luo, G.M., Song, H.Y., Lyons, T.W. and Canfield, D.E. (2015) Reconstruction of secular variation in seawater sulfate concentrations. Biogeosciences 12, 2131-2151.

Archer, C. and Vance, D. (2008) The isotopic signature of the global riverine molybdenum flux and anoxia in the ancient oceans. Nat. Geosci. 1, 597-600.

Arnold, G.L., Anbar, A.D., Barling, J. and Lyons, T.W. (2004) Molybdenum isotope evidence for widespread anoxia in mid-Proterozoic oceans. Science 304, 87-90.

Arnold, G.L., Lyons, T.W., Gordon, G.W. and Anbar, A.D. (2012) Extreme change in sulfide concentrations in the Black Sea during the Little Ice Age reconstructed using molybdenum isotopes. Geology 40, 595-598.

Barling, J. and Anbar, A.D. (2004) Molybdenum isotope fractionation during adsorption by manganese oxides. Earth. Planet. Sci. Lett. 217, 315-329.

Berrang, P. and Grill, E. (1974) The effect of manganese oxide scavenging on molybdenum in Saanich Inlet, British Columbia. Mar. Chem. 2, 125-148.

Canfield, D.E., Poulton, S.W., Knoll, A.H., Narbonne, G.M., Ross, G., Goldberg, T. and Strauss, H. (2008) Ferruginous conditions dominated later neoproterozoic deep-water chemistry. Science 321, 949-952.

Chen, D., Wang, J., Qing, H., Yan, D. and Li, R. (2009) Hydrothermal venting activities in the Early Cambrian, South China: Petrological, geochronological and stable isotopic constraints. Chem. Geol. 258, 168-181.

Chen, X., Ling, H.F., Vance, D., Shields-Zhou, G.A., Zhu, M., Poulton, S.W., Och, L.M., Jiang, S.Y., Li, D., Cremonese, L. and Archer, C. (2015) Rise to modern levels of ocean oxygenation coincided with the Cambrian radiation of animals. Nat. Commun. 6, 7142.

Cheng, M., Li, C., Zhou, L. and Xie, S.C. (2015) Mo marine geochemistry and reconstruction of ancient ocean redox states. Sci. China-Earth Sci. 58, 2123-2133.

Clarkson, M.O., Poulton, S.W., Guilbaud, R. and Wood, R.A. (2014) Assessing the utility of Fe/Al and Fe-speciation to record water column redox conditions in carbonate-rich sediments. Chem. Geol. 382, 111-122.

Cohen, K.M., Finney, S.C., Gibbard, P.L. and Fan, J.X. (2013; updated) The ICS International chronostratigraphic chart. Episodes 36, 199-204.

Collier, R.W. (1985) Molybdenum in the northeast Pacific Ocean. Limnol. Oceanogr. 30, 1351-1354.

Dahl, T.W., Hammarlund, E.U., Anbar, A.D., Bond, D.P.G., Gill, B.C., Gordon, G.W., Knoll, A.H., Nielsen, A.T., Schovsbo, N.H. and Canfield, D.E. (2010) Devonian rise in atmospheric oxygen correlated to the radiations of terrestrial plants and large predatory fish. Proc. Natl. Acad. Sci. U. S. A. 107, 17911-17915.

Dahl, T.W., Canfield, D.E., Rosing, M.T., Frei, R.E., Gordon, G.W., Knoll, A.H. and Anbar, A.D. (2011) Molybdenum evidence for expansive sulfidic water masses in 750 Ma oceans. Earth. Planet. Sci. 
Lett. 311, 264-274.

Dahl, T.W., Ruhl, M., Hammarlund, E.U., Canfield, D.E., Rosing, M.T. and Bjerrum, C.J. (2013) Tracing euxinia by molybdenum concentrations in sediments using handheld X-ray fluorescence spectroscopy (HHXRF). Chem. Geol. 360-361, 241-251.

Dellwig, O., Leipe, T., März, C., Glockzin, M., Pollehne, F., Schnetger, B., Yakushev, E.V., Böttcher, M.E. and Brumsack, H.J. (2010) A new particulate Mn-Fe-P-shuttle at the redoxcline of anoxic basins. Geochim. Cosmochim. Acta 74, 7100-7115.

Erickson, B.E. and Helz, G.R. (2000) Molybdenum(VI) speciation in sulfidic waters: Stabiloty and lability of thiomolybdates. Geochim. Cosmochim. Acta 64, 1149-1158.

Erwin, D.H., Laflamme, M., Tweedt, S.M., Sperling, E.A., Pisani, D. and Peterson, K.J. (2011) The Cambrian conundrum: early divergence and later ecological success in the early history of animals. Science 334, 1091-1097.

Feng, L., Li, C., Huang, J., Chang, H. and Chu, X. (2014) A sulfate control on marine mid-depth euxinia on the early Cambrian (ca. 529-521 Ma) Yangtze platform, South China. Precambr. Res. 246, 123-133.

Francois, R. (1988) A study on the regulation of the concentrations of some trace metals ( $\mathrm{Rb}, \mathrm{Sr}, \mathrm{Zn}, \mathrm{Pb}$, $\mathrm{Cu}, \mathrm{V}, \mathrm{Cr}, \mathrm{Ni}, \mathrm{Mn}$ and Mo) in Saanich Inlet sediments, British Columbia, Canada. Mar. Geol. 83, 285-308.

Fu, Y., Dong, L., Li, C., Qu, W., Pei, H., Qiao, W. and Shen, B. (2016) New Re-Os Isotopic Constrains on the Formation of the Metalliferous Deposits of the Lower Cambrian Niutitang Formation. $J$. Earth Sci. 27, 271-281.

Goldberg, T., Strauss, H., Guo, Q. and Liu, C. (2007) Reconstructing marine redox conditions for the Early Cambrian Yangtze Platform: Evidence from biogenic sulphur and organic carbon isotopes. Palaeogeogr. Palaeoclimatol. Palaeoecol. 254, 175-193.

Goldberg, T., Archer, C., Vance, D. and Poulton, S.W. (2009) Mo isotope fractionation during adsorption to Fe (oxyhydr)oxides. Geochim. Cosmochim. Acta 73, 6502-6516.

Goldberg, T., Gordon, G., Izon, G., Archer, C., Pearce, C.R., McManus, J., Anbar, A.D. and Rehkämper, M. (2013) Resolution of inter-laboratory discrepancies in Mo isotope data: an intercalibration. $J$. Annal. Atom. Spectrom. 28, 724-735.

Guilbaud, R., Poulton, S.W., Butterfield, N.J., Zhu, M. and Shields-Zhou, G.A. (2015) A global transition to ferruginous conditions in the early Neoproterozoic oceans. Nat. Geosci. 8, 466-470.

Guo, Q., Shields, G.A., Liu, C., Strauss, H., Zhu, M., Pi, D., Goldberg, T. and Yang, X. (2007) Trace element chemostratigraphy of two Ediacaran-Cambrian successions in South China: Implications for organosedimentary metal enrichment and silicification in the Early Cambrian. Palaeogeogr. Palaeoclimatol. Palaeoecol. 254, 194-216.

Guo, Q., Strauss, H., Zhao, Y., Yang, X., Peng, J., Yang, Y. and Deng, Y. (2014) Reconstructing marine redox conditions for the transition between Cambrian Series 2 and Cambrian Series 3, Kaili area, Yangtze Platform: Evidence from biogenic sulfur and degree of pyritization. Palaeogeogr. Palaeoclimatol. Palaeoecol. 398, 144-153.

Helz, G.R., Miller, C.V., Charnock, J.M., Mosselmans, J.F.W., Pattrick, R.A.D., Garner, C.D. and Vaughan, D.J. (1996) Mechanism of molybdenum removal from the sea and its concentration in black shales: EXAFS evidence. Geochim. Cosmochim. Acta 60, 3631-3642.

Helz, G.R., Bura-Nakić, E., Mikac, N. and Ciglenečki, I. (2011) New model for molybdenum behavior in euxinic waters. Chem. Geol. 284, 323-332.

Jiang, G., Kennedy, M.J. and Christie-Blick, N. (2003) Stable isotopic evidence for methane seeps in Neoproterozoic postglacial cap carbonates. Nature 426, 822-826.

Jiang, G., Kaufman, A.J., Christie-Blick, N., Zhang, S. and Wu, H. (2007) Carbon isotope variability across the Ediacaran Yangtze platform in South China: Implications for a large surface-to-deep ocean $\delta^{13} \mathrm{C}$ gradient. Earth. Planet. Sci. Lett. 261, 303-320.

Jiang, G., Shi, X., Zhang, S., Wang, Y. and Xiao, S. (2011) Stratigraphy and paleogeography of the Ediacaran Doushantuo Formation (ca. 635-551 Ma) in South China. Gondwana Res. 19, 831-849. 
Jiang, S.Y., Pi, D.H., Heubeck, C., Frimmel, H., Liu, Y.P., Deng, H.L., Ling, H.F. and Yang, J.H. (2009) Early Cambrian ocean anoxia in South China. Nature 459, E5-6; discussion E6.

Jin, C., Li, C., Peng, X., Cui, H., Shi, W., Zhang, Z., Luo, G. and Xie, S. (2014) Spatiotemporal variability of ocean chemistry in the early Cambrian, South China. Sci. China-Earth Sci. 57, 579-591.

Jin, C., Li, C., Algeo, T.J., Planavsky, N.J., Cui, H., Yang, X., Zhao, Y., Zhang, X. and Xie, S. (2016) A highly redox-heterogeneous ocean in South China during the early Cambrian ( 529-514 Ma): Implications for biota-environment co-evolution. Earth. Planet. Sci. Lett. 441, 38-51.

Kendall, B., Creaser, R.A., Gordon, G.W. and Anbar, A.D. (2009) Re-Os and Mo isotope systematics of black shales from the Middle Proterozoic Velkerri and Wollogorang Formations, McArthur Basin, northern Australia. Geochim. Cosmochim. Acta 73, 2534-2558.

Kendall, B., Gordon, G.W., Poulton, S.W. and Anbar, A.D. (2011) Molybdenum isotope constraints on the extent of late Paleoproterozoic ocean euxinia. Earth. Planet. Sci. Lett. 307, 450-460.

Kendall, B., Komiya, T., Lyons, T.W., Bates, S.M., Gordon, G.W., Romaniello, S.J., Jiang, G.Q., Creaser, R.A., Xiao, S.H., McFadden, K., Sawaki, Y., Tahata, M., Shu, D.G., Han, J., Li, Y., Chu, X.L. and Anbar, A.D. (2015) Uranium and molybdenum isotope evidence for an episode of widespread ocean oxygenation during the late Ediacaran Period. Geochim. Cosmochim. Acta 156, 173-193.

Knoll, A.H. and Carroll, S.B. (1999) Early animal evolution: Emerging views from comparative biology and geology. Science 284, 2129-2137.

Komura, H. and Watanabe, Y. (2001) Oceanic anoxia at the Precambrian-Cambrian boundary. Geology 29, 995-998.

Lehmann, B., Nägler, T.F., Holland, H.D., Wille, M., Mao, J., Pan, J., Ma, D. and Dulski, P. (2007) Highly metalliferous carbonaceous shale and Early Cambrian seawater. Geology 35, 403-406.

Li, C., Love, G.D., Lyons, T.W., Fike, D.A., Sessions, A.L. and Chu, X. (2010) A stratified redox model for the Ediacaran ocean. Science 328, 80-83.

Li, C., Cheng, M., Algeo, T.J. and Xie, S. (2015) A theoretical prediction of chemical zonation in early oceans (>520 Ma). Sci. China-Earth Sci. 58, 1901-1909.

Li, D., Ling, H.F., Shields Zhou, G.A., Chen, X., Cremonese, L., Och, L., Thirlwall, M. and Manning, C.J. (2013) Carbon and strontium isotope evolution of seawater across the Ediacaran-Cambrian transition: Evidence from the Xiaotan section, NE Yunnan, South China. Precambr. Res. 225, $128-147$

Li, X.H., Li, W.X., Li, Z.X., Lo, C.H., Wang, J., Ye, M.F. and Yang, Y.H. (2009) Amalgamation between the Yangtze and Cathaysia Blocks in South China: Constraints from SHRIMP U-Pb zircon ages, geochemistry and Nd-Hf isotopes of the Shuangxiwu volcanic rocks. Precambr. Res. 174, 117-128.

Li, Z.X., Bogdanova, S.V., Collins, A.S., Davidson, A., De Waele, B., Ernst, R.E., Fitzsimons, I.C.W., Fuck, R.A., Gladkochub, D.P., Jacobs, J., Karlstrom, K.E., Lu, S., Natapov, L.M., Pease, V., Pisarevsky, S.A., Thrane, K. and Vernikovsky, V. (2008) Assembly, configuration, and break-up history of Rodinia: A synthesis. Precambr. Res. 160, 179-210.

Loyd, S.J., Marenco, P.J., Hagadorn, J.W., Lyons, T.W., Kaufman, A.J., Sour-Tovar, F. and Corsetti, F.A (2012) Sustained low marine sulfate concentrations from the Neoproterozoic to the Cambrian: Insights from carbonates of northwestern Mexico and eastern California. Earth. Planet. Sci. Lett. 339-340, 79-94.

Lyons, T.W., Reinhard, C.T. and Planavsky, N.J. (2014) The rise of oxygen in Earth's early ocean and atmosphere. Nature 506, 307-315.

McLennan, S.M. (2001) Relationships between the trace element composition of sedimentary rocks and upper continental crust. Geochem. Geophys. Geosyst. 2, DOI: 10.1029/2000GC000109.

Miller, C.A., Peucker-Ehrenbrink, B., Walker, B.D. and Marcantonio, F. (2011) Re-assessing the surface cycling of molybdenum and rhenium. Geochim. Cosmochim. Acta 75, 7146-7179.

Miller, K.G., Kominz, M.A., Browning, J.V., Wright, J.D., Mountain, G.S., Katz, M.E., Sugarman, P.J., 
Cramer, B.S., Christie-Blick, N. and Pekar, S.F. (2006) The Phanerozoic record of global sea-level change. Science 310, 1293-1298.

Morford, J.L. and Emerson, S. (1999) The geochemistry of redox sensitive trace metals in sediments. Geochim. Cosmochim. Acta 63, 1735-1750.

Morford, J.L., Emerson, S.R., Breckel, E.J. and Kim, S.H. (2005) Diagenesis of oxyanions (V, U, Re, and $\mathrm{Mo}$ ) in pore waters and sediments from a continental margin. Geochim. Cosmochim. Acta 69, 5021-5032.

Morford, J.L., Martin, W.R., François, R. and Carney, C.M. (2009) A model for uranium, rhenium, and molybdenum diagenesis in marine sediments based on results from coastal locations. Geochim. Cosmochim. Acta 73, 2938-2960.

Nägler, T.F., Anbar, A.D., Archer, C., Goldberg, T., Gordon, G.W., Greber, N.D., Siebert, C., Sohrin, Y. and Vance, D. (2013) Proposal for an International Molybdenum Isotope Measurement Standard and Data Representation. Geostand. Geoanal. Res. 38, 149-151.

Neubert, N., Nägler, T.F. and Böttcher, M.E. (2008) Sulfidity controls molybdenum isotope fractionation into euxinic sediments: Evidence from the modern Black Sea. Geology 36, 775-778.

Och, L.M., Shields-Zhou, G.A., Poulton, S.W., Manning, C., Thirlwall, M.F., Li, D., Chen, X., Ling, H., Osborn, T. and Cremonese, L. (2013) Redox changes in Early Cambrian black shales at Xiaotan section, Yunnan Province, South China. Precambr. Res. 225, 166-189.

Okada, Y., Sawaki, Y., Komiya, T., Hirata, T., Takahata, N., Sano, Y., Han, J. and Maruyama, S. (2014) New chronological constraints for Cryogenian to Cambrian rocks in the Three Gorges, Weng'an and Chengjiang areas, South China. Gondwana Res. 25, 1027-1044.

Pakhomova, S. and Yakushev, E.V. (2011) Manganese and iron at the redox Interfaces in the Black Sea, the Baltic Sea, and the Oslo Fjord, The Handbook of Environmental Chemistry, 22 ed. Springer-Verlag Berlin Heidelberg, pp. 67-93.

Peng, S.B., Kusky, T.M., Zhou, H.W., Wang, L. and Xiang, W. (2012) New research progress on the pre-Sinian tectonic evolution and neotectonics of the Huangling anticline region, South China. $J$. Earth Sci. 23, 639-647.

Planavsky, N.J., McGoldrick, P., Scott, C.T., Li, C., Reinhard, C.T., Kelly, A.E., Chu, X., Bekker, A., Love, G.D. and Lyons, T.W. (2011) Widespread iron-rich conditions in the mid-Proterozoic ocean. Nature 477, 448-451.

Poulson, R.L., Siebert, C., McManus, J. and Berelson, W.M. (2006) Authigenic molybdenum isotope signatures in marine sediments. Geology 34, 617-620.

Poulton, S.W., Fralick, P.W. and Canfield, D.E. (2010) Spatial variability in oceanic redox structure 1.8 billion years ago. Nat. Geosci. 3, 486-490.

Poulton, S.W. and Canfield, D.E. (2011) Ferruginous conditions: A dominant feature of the ocean through Earth's history. Elements 7, 107-112.

Raiswell, R. and Canfield, D. (2012) The iron biogeochemical cycle past and present. Geochem. Persp. 1, 1-220.

Scholz, F., McManus, J. and Sommer, S. (2013) The manganese and iron shuttle in a modern euxinic basin and implications for molybdenum cycling at euxinic ocean margins. Chem. Geol. 355, 56-68.

Scott, C., Lyons, T.W., Bekker, A., Shen, Y., Poulton, S.W., Chu, X. and Anbar, A.D. (2008) Tracing the stepwise oxygenation of the Proterozoic ocean. Nature 452, 456-459.

Scott, C. and Lyons, T.W. (2012) Contrasting molybdenum cycling and isotopic properties in euxinic versus non-euxinic sediments and sedimentary rocks: Refining the paleoproxies. Chem. Geol. 324, 19-27.

Shimmield, G.B. and Price, N.B. (1986) The behaviour of molybdenum and manganese during early sediment diagenesis_ offshore Baja California, Mexico. Mar. Chem. 19, 261-280.

Siebert, C., Nägler, T.F., von Blanckenburg, F. and Kramers, J.D. (2003) Molybdenum isotope records as a potential new proxy for paleoceanography. Earth. Planet. Sci. Lett. 211, 159-171. 
Steiner, M., Li, G., Qian, Y. and Zhu, M. (2004) Lower Cambrian small shelly fossils of northern Sichuan and southern Shaanxi (China), and their biostratigraphic importance. Geobios 37, 259-275.

Steiner, M., Li, G., Qian, Y., Zhu, M. and Erdtmann, B.D. (2007) Neoproterozoic to Early Cambrian small shelly fossil assemblages and a revised biostratigraphic correlation of the Yangtze Platform (China). Palaeogeogr. Palaeoclimatol. Palaeoecol. 254, 67-99.

Tribovillard, N., Algeo, T.J., Lyons, T. and Riboulleau, A. (2006) Trace metals as paleoredox and paleoproductivity proxies: An update. Chem. Geol. 232, 12-32.

Trouwborst, R.E., Clement, B.G., Tebo, B.M., Glazer, B.T. and Luther, G.W. (2006) Soluble Mn(III) in suboxic zones. Science 313, 1955-1957.

Voegelin, A.R., Pettke, T., Greber, N.D., von Niederhäusern, B. and Nägler, T.F. (2014) Magma differentiation fractionates Mo isotope ratios: Evidence from the Kos Plateau Tuff (Aegean Arc). Lithos 190-191, 440-448.

Wang, J. and Li, Z.X. (2003) History of Neoproterozoic rift basins in South China: implications for Rodinia break-up. Precambr. Res. 122, 141-158.

Wang, J., Chen, D., Yan, D., Wei, H. and Xiang, L. (2012) Evolution from an anoxic to oxic deep ocean during the Ediacaran-Cambrian transition and implications for bioradiation. Chem. Geol. 306-307, 129-138.

Wang, X., Erdtmann, B.D., Chen, X. and Mao, X. (1998) Integrated sequence-, bio-and chemo-stratigraphy of the terminal Proterozoic to Lowermost Cambrian" black rock series" from central South China. Episodes 21, 178.

Wasylenki, L.E., Weeks, C.L., Bargar, J.R., Spiro, T.G., Hein, J.R. and Anbar, A.D. (2011) The molecular mechanism of Mo isotope fractionation during adsorption to birnessite. Geochim. Cosmochim. Acta 75, 5019-5031.

Wen, H., Carignan, J., Zhang, Y., Fan, H., Cloquet, C. and Liu, S. (2011) Molybdenum isotopic records across the Precambrian-Cambrian boundary. Geology 39, 775-778.

Wen, H., Carignan, J., Chu, X., Fan, H., Cloquet, C., Huang, J., Zhang, Y. and Chang, H. (2014) Selenium isotopes trace anoxic and ferruginous seawater conditions in the Early Cambrian. Chem. Geol. 390, 164-172.

Wen, H., Fan, H., Zhang, Y., Cloquet, C. and Carignan, J. (2015) Reconstruction of early Cambrian ocean chemistry from Mo isotopes. Geochim. Cosmochim. Acta 164, 1-16.

Wille, M., Nägler, T.F., Lehmann, B., Schröder, S. and Kramers, J.D. (2008) Hydrogen sulphide release to surface waters at the Precambrian/Cambrian boundary. Nature 453, 767-769.

Xiao, S., Hu, J., Yuan, X., Parsley, R.L. and Cao, R. (2005) Articulated sponges from the Lower Cambrian Hetang Formation in southern Anhui, South China: their age and implications for the early evolution of sponges. Palaeogeogr. Palaeoclimatol. Palaeoecol. 220, 89-117.

Xu, L., Lehmann, B., Mao, J., Nägler, T.F., Neubert, N., Böttcher, M.E. and Escher, P. (2012) Mo isotope and trace element patterns of Lower Cambrian black shales in South China: Multi-proxy constraints on the paleoenvironment. Chem. Geol. 318-319, 45-59.

Xu, L.G., Lehmann, B., Mao, J.W., Qu, W.J. and Du, A.D. (2011) Re-Os age of polymetallic Ni-Mo-PGE-Au mineralization in Early Cambrian black shales of south China-A reassessment. Econ. Geol. 106, 511-522.

Yin, G.Z., He, T.G., Qian, Y. and Xiao, B. (1999) Geological and geographical distribution of SSF, with discussion on Early Cambrian geogrephical provinces, in: Qian, Y. (Ed.), Taxonomy and biostratigraphy of small shelly fossils in China. Science Press, Beijing, pp. 234-240.

Yu, B., Dong, H., Widom, E., Chen, J. and Lin, C. (2009) Geochemistry of basal Cambrian black shales and cherts from the Northern Tarim Basin, Northwest China: Implications for depositional setting and tectonic history. J. Asian Earth Sci. 34, 418-436.

Zhang, L. (2014) Study on the biota and its co-evolution to the paleoenvironment in the early Cambrian of the eastern Yangtze Gorges and western Zhejiang, China, Phd thesis. China University of Geosciences, Wuhan, p. 142. 
Zhou, L., Algeo, T.J., Shen, J., Hu, Z.F., Gong, H.M., Xie, S.C., Huang, J.H. and Gao, S. (2015) Changes in marine productivity and redox conditions during the Late Ordovician Hirnantian glaciation. Palaeogeogr. Palaeoclimatol. Palaeoecol. 420, 223-234.

Zhu, M., Li, G., Zhang, J., Steiner, M., Qian, Y. and Jiang, Z. (2001) Early Cambrian stratigraphy of east Yunnan, southwestern China: a synthesis. Acta Palaeontol. Sin. 40, 4-39.

Zhu, M., Zhang, J., Steiner, M., Yang, A., Li, G. and Erdtmann, B.D. (2003) Sinian-Cambrian stratigraphic framework for shallow- to deep-water environments of the Yangtze Platform: an integrated approach. Proc. Nat. Sci. 13, 951-960.

Zhu, M., Lu, M., Zhang, J., Zhao, F., Li, G., Aihua, Y., Zhao, X. and Zhao, M. (2013) Carbon isotope chemostratigraphy and sedimentary facies evolution of the Ediacaran Doushantuo Formation in western Hubei, South China. Precambr. Res. 225, 7-28. 


\section{FIGURE CAPTIONS}

Figure 1. Geological setting of the Yangjiaping section. (A) Global paleogeography in the early Cambrian (adapted from Li et al., 2008). (B) Simplified tectonic-lithofacies map of South China during the Fortunian (modified from Goldberg et al., 2007). (C) Generalized stratigraphy of the Yangjiaping section (modified from Feng et al., 2014). Ed = Ediacaran, $\mathrm{Ft}=$ Fortunian, $\mathrm{St}=\mathrm{Stage}$, MSC $=$ Meishucunian, DY = Dengying Formation, $\mathrm{LM}=$ lower member $($ black shale interval) and $\mathrm{UM}=$ upper member (silty shale interval). Biostratigraphic data are from Steiner et al. (2004) and Yin et al. (1999). The radiometric age of 526.4 $\pm 5.4 \mathrm{Ma}$ is from the adjacent Three Gorges section Okada et al. (2014).

Figure 2. Chemostratigraphy of the LM and UM of the Niutitang Formation at Yangiaping. The Mo-isotope and Mn, $\mathrm{U}$, and $\mathrm{V}$ abundance data are original to this study; the remaining data were compiled from Feng et al. (2014). The vertical dashed lines in boxes denote key values of geochemical proxies as discussed in text. $\mathrm{LM}=$ lower member and $\mathrm{UM}=$ upper member.

Figure 3. Crossplot of Mo versus TOC. The data shown are for the LM and UM of the Niutitang Formation at Yangjiaping and correlative units from multiple other sections of the Yangtze Block, including the inner-shelf sections at Xiaotan (Och et al., 2013) and Shatan (Goldberg et al., 2007), the outer shelf to shelf margin sections at Dingtai (Xu et al., 2011) and Yangjiaping (Feng et al., 2014 and this study), and the upper-slope sections at Songtao (Guo et al., 2007) and Zhitang (Zhang, 2014). The dashed green trend lines (numbers are given as mean $\pm 1 \sigma$ ) were adopted from Algeo and Lyons (2006), and the solid blue trend line is the average [number is given as median $\left(16^{\text {th }}-84^{\text {th }}\right.$ percentile range) to remove several over-scattering data] for all lower Cambrian units of the Yangtze Block. $\mathrm{LM}=$ lower member and $\mathrm{UM}=$ upper member.

Figure 4. A histogram of sample frequencies of $\delta^{98}$ Mo values. The data shown are for the study Niutitang shales at Yangjiaping (this study) and correlative units from multiple other sections of 
the Yangtze Block, including Meishucun (Wen et al., 2015), Zunyi (Xu et al., 2012; Wen et al., 2015), Longbizui (Chen et al., 2015), Jijiawan (Chen et al., 2015), and Huangjiawan (Lehmann et al., 2007).

Figure 5. Crossplots of (A) Mn versus $\mathrm{Fe}_{\mathrm{T}}$, and (B) $\mathrm{Mo}_{\mathrm{EF}}$ versus $\mathrm{U}_{\mathrm{EF}}$. The data shown are for the study Niutitang shales (LM and UM) at Yangjiaping and (in B) correlative units from multiple other sections of the Yangtze Block (as given in the Fig. 3 caption). The trend lines in B are modified from_Algeo and Tribovillard (2009). LM = lower member and UM = upper member.

Figure 6. Schematic representation of the Mo cycle in the early Cambrian ocean within the framework of a modified "euxinic wedge model". SWI = sediment-water interface, aq = aqueous, $\mathrm{SW}=$ seawater, $\mathrm{PW}=$ porewater. See text for detailed explanation. 


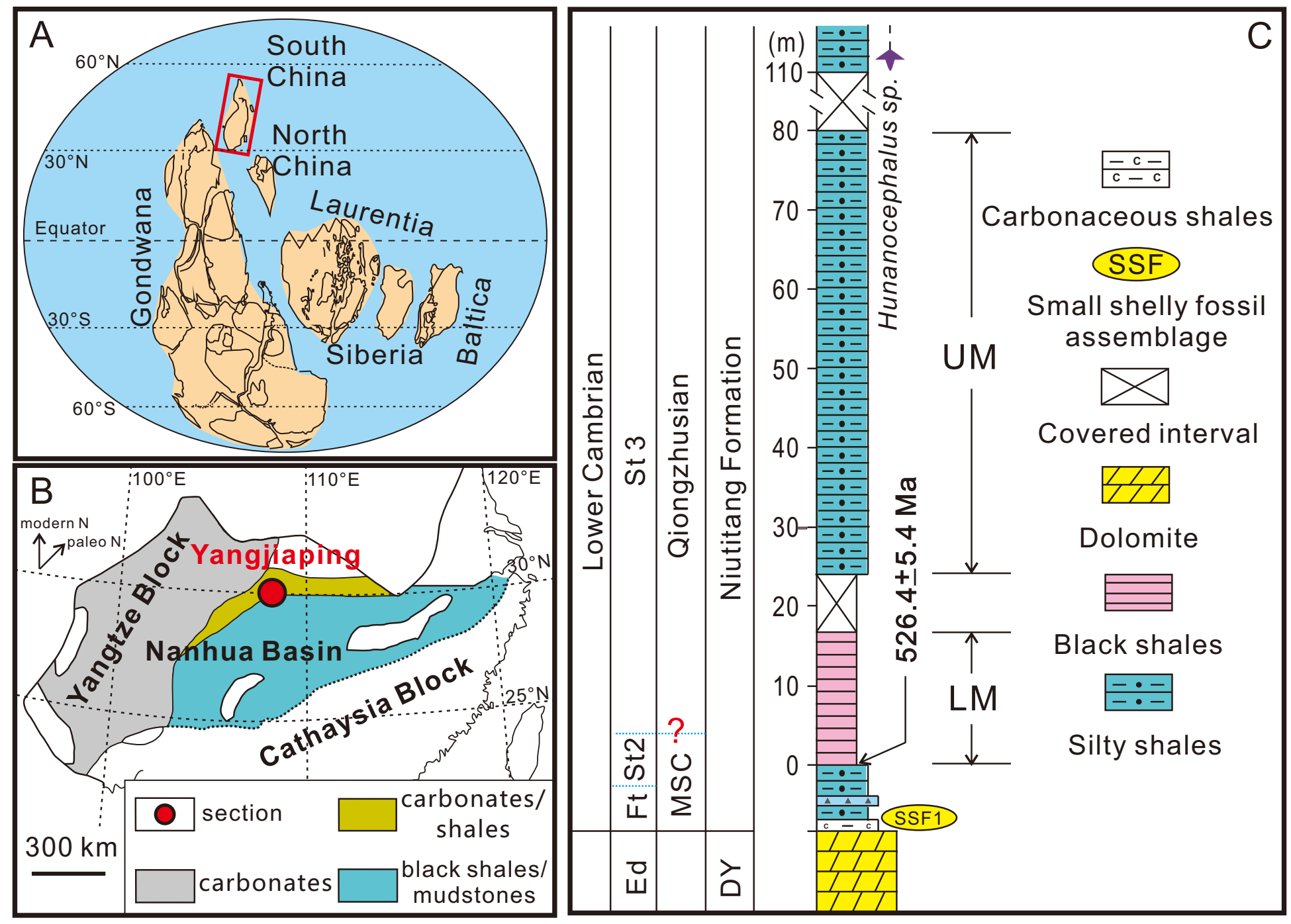




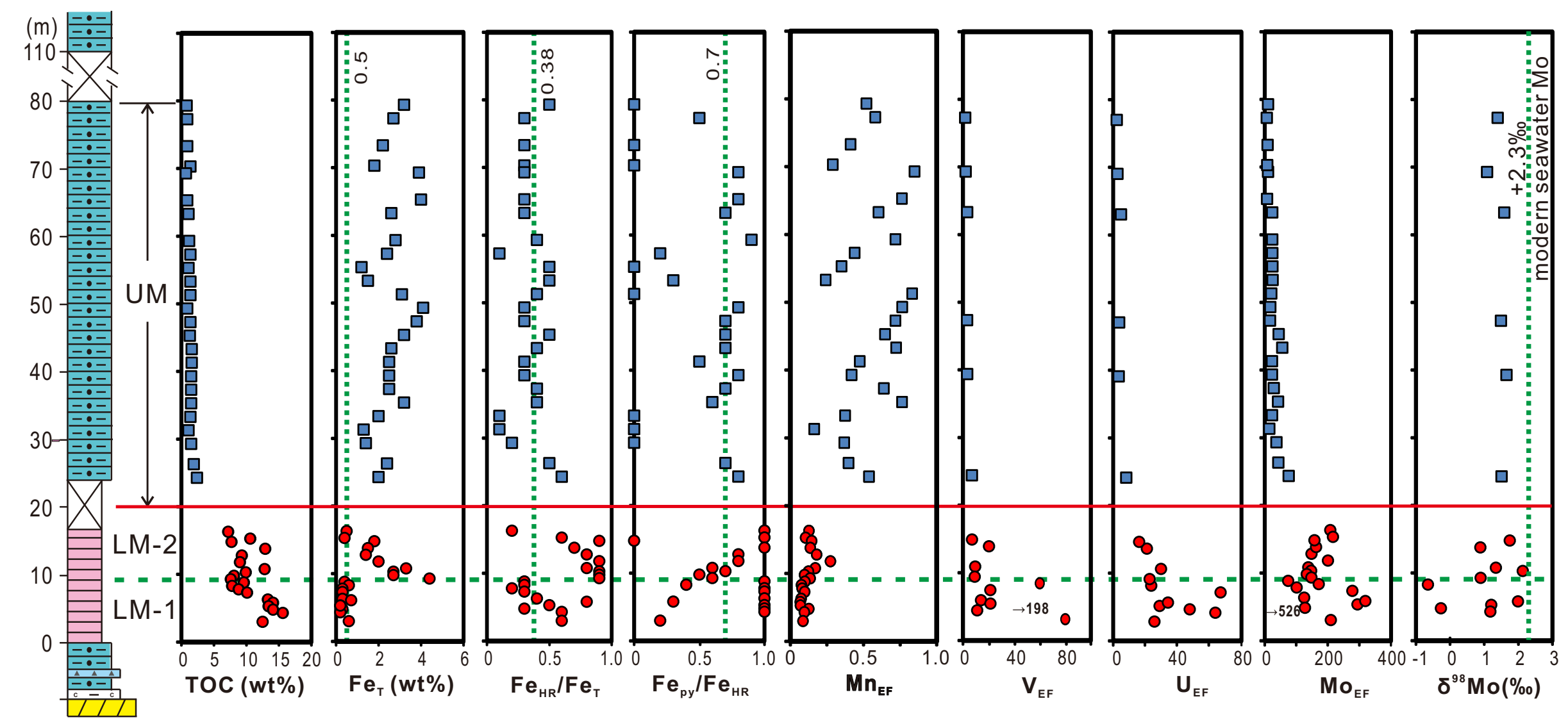




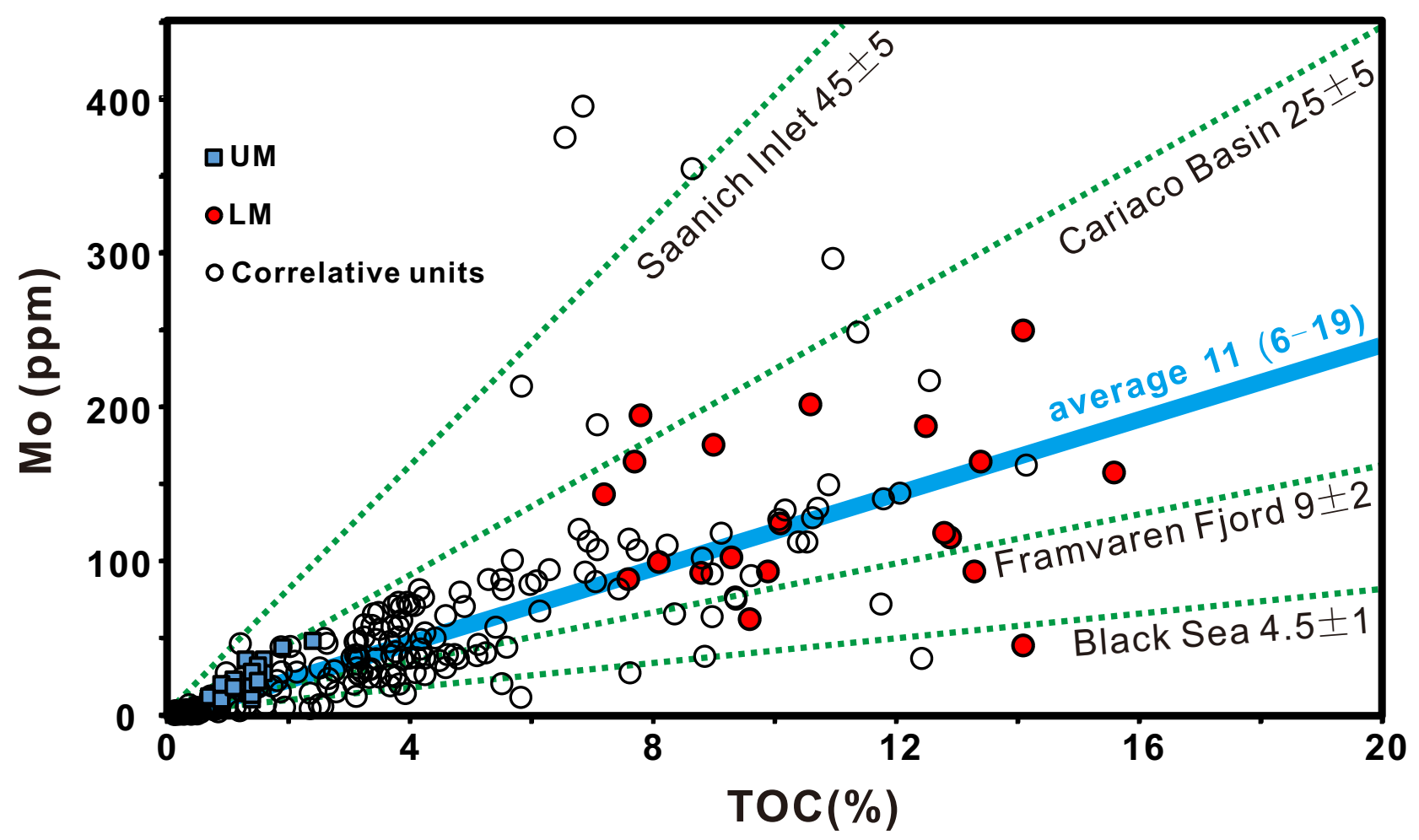


Figure 4

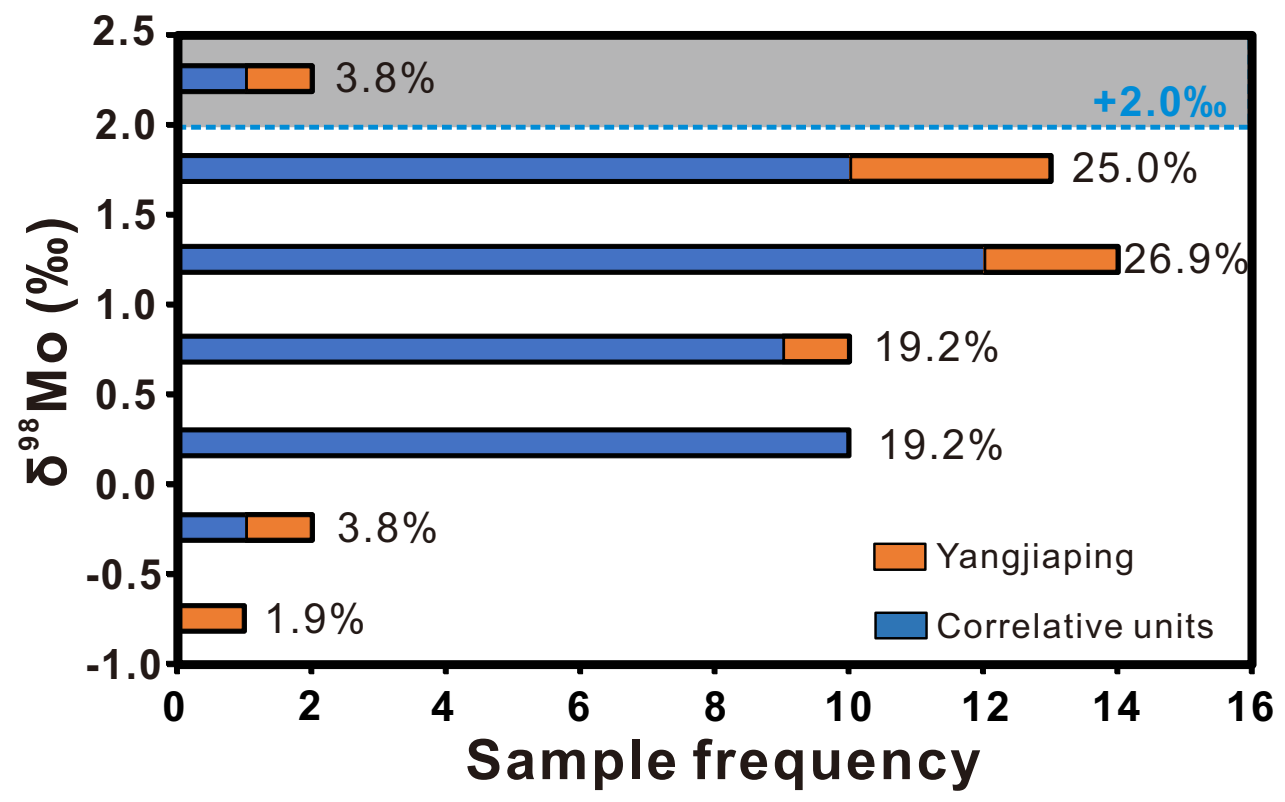


Figure 5
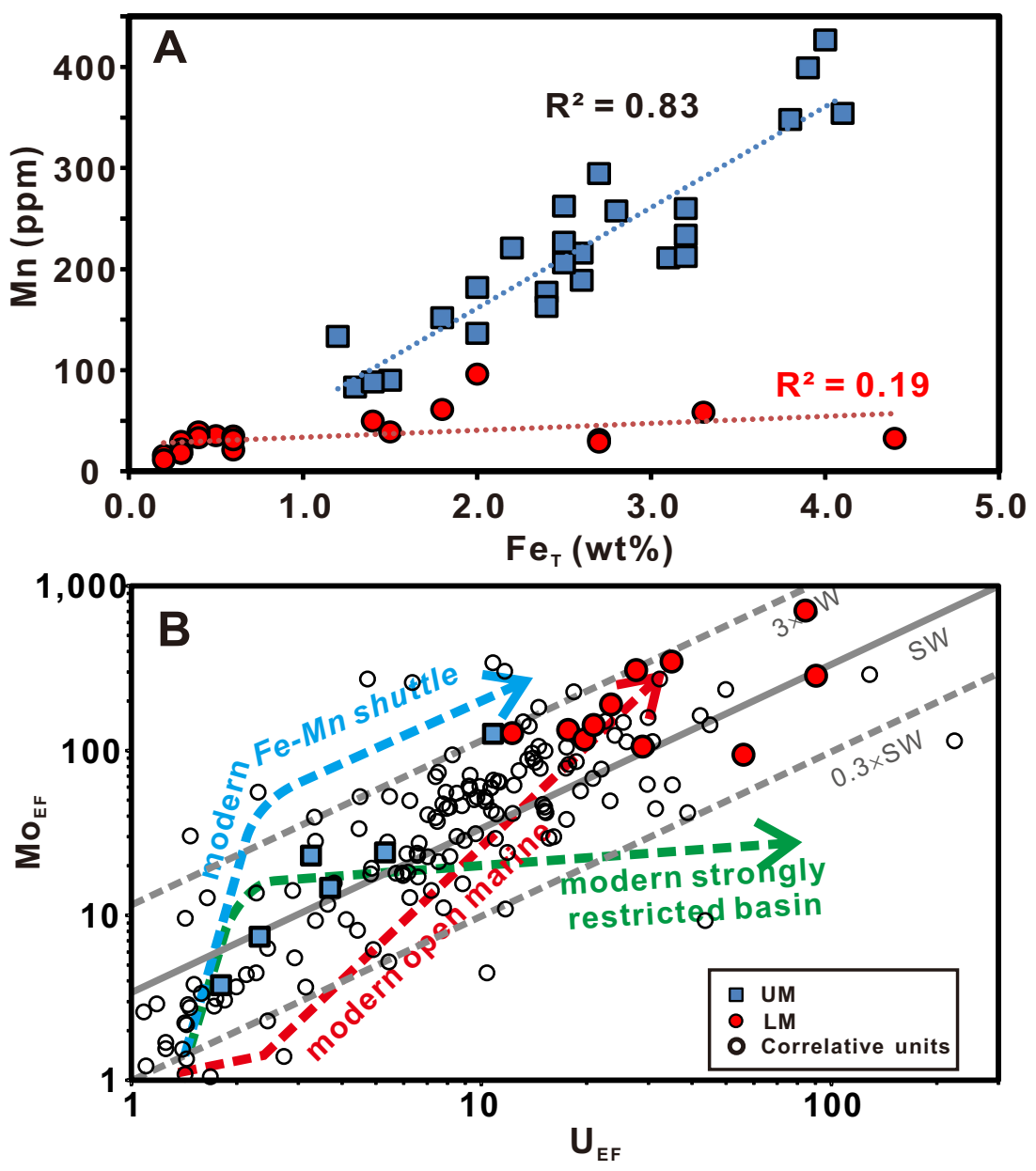
Figure 6

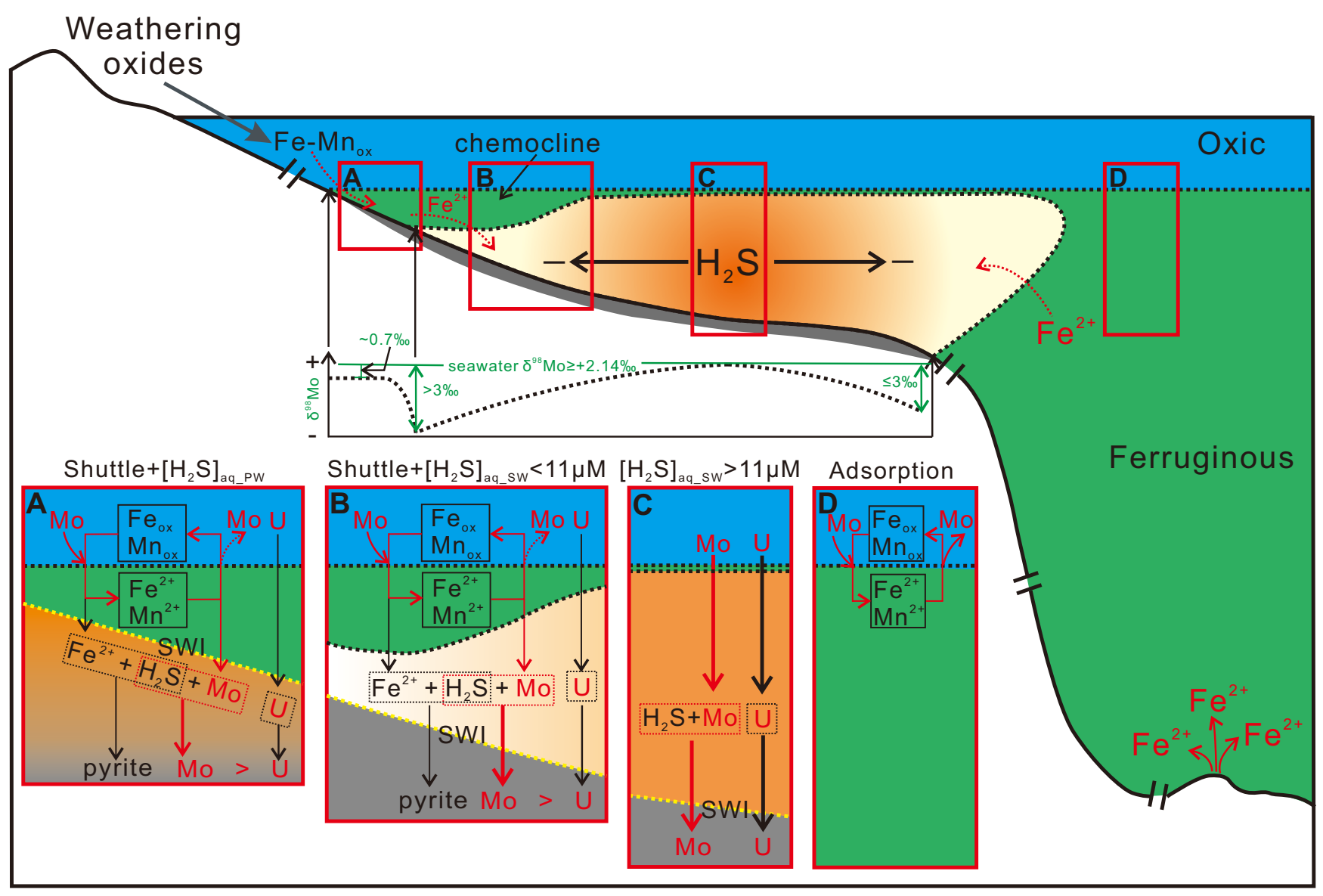

